\title{
The Secretory Glands of Asphodelus aestivus Flower
}

\author{
Thomas Sawidis \\ Department of Botany, \\ University of Thessaloniki, Thessaloniki, Macedonia,
}

Greece

\section{Introduction}

Asphodelus aestivus Brot. (A. microcarpus Viv.), family of Asphodelaceae (Asparagales), is a perennial spring-flowering geophyte, widely distributed over the Mediterranean basin (Tutin et al., 1980). Its formations represent the last degradation stage of the Mediterranean type ecosystems. These ecosystems often referred to as "asphodel deserts" or "asphodel semideserts" result from drought, frequent fires, soil erosion and overgrazing (Naveh, 1973; Pantis \& Margaris, 1988). It is found both in arid and semi-arid Mediterranean ecosystems (Margaris, 1984) and in certain regions of North Africa (Le Houerou, 1979). A. aestivus, as in the case of other geophytes (cryptophytes), has a considerable distribution, since it has become the dominant life form in many degraded Mediterranean ecosystems. It is a widespread and invasive weed of the calcareous soils of pastures and grasslands, on hill slopes interspaced among cultivated areas, particularly abundant along road sides. The ability of A. aestivus, a native floristic element, to spread and to dominate in all those areas over the Mediterranean region reflects its capacity to face not only the peculiarities of the Mediterranean climate, but also to resist these most common disturbances in its habitat (Pantis \& Margaris, 1988).

A. aestivus has two major phenological phases within a year. An active one (autumn - late spring) from leaf emergence to the senescence of the above-ground structures (photosynthetic period) and an inactive (summer) phase (dormancy), which lasts until the leaves emerge (Pantis et al., 1994). In February - March, the over wintering root tubers develop flat leaves (40-90 cm long x 2-4 cm width) and flowering stalks $(70-170 \mathrm{~cm}$ tall) from a shoot apex. Fruiting starts in early May coinciding with the onset of leaf senescence. The fleshy leaves are herbivore protected by steroid saponins (Dahlgren et al., 1985) and senesce in June, before fruit maturation. The root tubers show lateral growth and vegetative propagation is frequent in mature plants. However, most of the root tubers remain attached to the mother plant. A. aestivus is a sessile organism reproducing by means of root tubers as well as by seeds. These facts are of considerable importance as far as maintenance and even dominance of $A$. aestivus within degraded areas are concerned.

The overproduction of flowers allows the plant to compensate for environmental variations and provides maternal chance in selective abortion of fruits and seeds (Stephenson, 1981; 
Sutherland, 1986; Lee, 1988; Ehrlen, 1991). It is proved that the percentage of flowering is linearly related to the availability of nutrients (Pantis, 1993). The entomophilous flower of $A$. aestivus secretes a considerable amount of nectar, which is involved in pollination. As in many other plants, nectar is used to reward insects, which in turn offer a beneficial relationship (Simpson, 1993). The main pollinators are bumblebees and honeybees. Knuth (1899) provided general information about the floral biology of A. albus and Daumann (1970) described the morphology of the nectary. The release of the nectar onto the nectary surface occurs with a variety of mechanisms. Nectar may diffuse through the thin secretory cell walls or may accumulate beneath the cuticle of the nectary cells until the cuticle ruptures by the foraging vector releasing the nectar (Sawidis et al., 1987; Sawidis et al., 1989; Fahn, 1990; Sawidis, 1991; Sawidis et al. 2008). The above-ground structures (inflorescence stalks and fleshy leaves) are completely dry by June, and only the root tubers survive the dry summer (dormancy).

Asphodel meadows had first been referred by Homer. According to his epics (Odyssey, XI, 539,573, XXIV , 13), the souls of the dead arrived in underground meadows "asphodelos leimon" on which only asphodels bloomed. The numerous underground root tubers of $A$. aestivus are up to $12 \mathrm{~cm}$ long and $4 \mathrm{~cm}$ thick. They have unlimited growth upwards, while the lower part breaks down. The age of the living part of a root tuber can be determined by the number of thickenings. The root tubers of A. aestivus, dried and boiled in water, yield a mucilaginous matter which in some countries, when mixed with flour or potato make the asphodel bread. In Spain and other countries, they are used as cattle and especially as sheep fodder. In Persia, a strong glue is made from the root tubers, which first become dried, pulverized and then mixed with cold water. Under the term "Tsirisse," the root tubers of Asphodelus bulbosus, were used in eastern countries as a mucilage and to adulterate powdered salep. The ultrastructure and function of $A$. aestivus root tubers have been studied in order to explain the abundance of this plant in the Mediterranean region (Sawidis et al., 2005).

Because of the importance of $A$. aestivus as a consistent component of the Mediterranean vegetation and its dominance over wide areas, the present study aimed to evaluate the combined role of flower secretory glands and the mechanisms that contribute to its remarkable distribution to the Mediterranean region. The ultimate goal is to determine the morphology, anatomy, fine structure and function of septal nectary, osmophores and obturator and to correlate these structures with the remarkable success on pollination mechanism, fruit setting and thus the abundance of $A$. aestivus in the Mediterranean region. Still, reports of secretory structures in A. aestivus and other geophytes and their secretion mechanism are fragmentary.

\section{Materials and methods}

One-year-old plants of $A$. aestivus were collected from a hill about $25 \mathrm{~km}$ southwest of Larissa, Thessaly, Central Greece. Asphodel semi-deserts in Thessaly (Fig. 1) occupy an area of about 10.000 ha which is gradually expanding due to overgrazing, frequent fires and soil erosion (Pantis \& Margaris, 1988). Flower buds of different age were sampled and floral parts were fixed with $2.5 \%$ glutaraldehyde and $2 \%$ paraformaldehyde in $0.05 \mathrm{M}$ cacodylate buffer for $3 \mathrm{~h}$. After post-fixation in $2 \%$ osmium tetroxide and dehydration in an ethanol series, the tissue was embedded in Spurr's epoxy resin. Cross sections were obtained in a 
Reichert-Jung Ultracut E ultramicrotome. Semi-thin sections of 0.5-1.0 $\mu \mathrm{m}$ thickness from resin embedded tissue were stained with $0.5 \%$ toluidine blue in $5 \%$ borax for preliminary light microscope (LM) observations. For qualitative detection of lignin in cell walls the cationic dye safranine $\mathrm{O}$ (1\% aqueous), that show an affinity for lignin, was used.

For transmission electron microscopy (TEM) ultrathin sections $(0.08 \mu \mathrm{m})$ were stained with 2 $\%(\mathrm{w} / \mathrm{v})$ uranyl acetate followed by $2 \%(\mathrm{w} / \mathrm{v})$ lead citrate. Ultrastructural observations were carried out a Zeiss 9 S-2 and a Jeol GEM 1011 TEM. For scanning electron microscopy (SEM), specimens were fixed in $4 \%$ glutaraldehyde cacodylate-buffered ( $\mathrm{pH} 7.0$ ) for 4 hours in room temperature without any osmium post fixation. After dehydration in an ethanol series $(10-100 \%)$, specimens were critical-point dried with liquid $\mathrm{CO}_{2}$ as an intermediate and coated with gold in a CS 100 Sputter Coater. Observations were made using a BS-340 Tesla scanning electron microscope at various accelerating potentials. For polysaccharide staining, semithin sections of fixed or fresh material were treated with the periodic acidSchiff's reagent (PAS) according to Nevalainen et al. (1972). For electron microscopic examination of polysaccharides ultrathin sections, collected on gold grids, were treated with periodic acid-thiosemicarbazide silver proteinate (PA-TCH-SP), according to Thiery (1967), following a procedure outlined by Roland (1978).

\section{Results}

\subsection{Floral morphology}

The flowers of $A$. aestivus are joined together in multi-branched pyramidal panicles. The number of flowers per inflorescence varies from 400 to 600 in April - May. In every cluster, the bottom flowers open first and then follow the above flowers. Every single flower remains in bloom for several days. The number of open flowers per inflorescence on the same day can be up to 30 . The perianth of the actinomorphic flower consists of a distinct, heavily sclerefied calyx and corolla of six petals. The elongated white petals have a red/purple stripe through the centre. The centrally located gynoecium has a superior, spherical ovary with six distinct furrows (Fig. 2).

It is enclosed by a salmon/orange cap which is formed by six flaps, each coming from the base of each stamen. The light green ovary is well set off from the white, narrow and nonbranched central style with slightly swollen stigma. The trilocular ovary has isomerous carpels, the lateral faces of which are united by fusion with one another (syncarpous gynoecium). In the middle of the ovary a hole connecting the septal slid and the outer space exists (Fig. 3). This hole (one per chamber) is the opening of the nectar and has the form of a groove which may be of different lengths. In younger flowers, the opening is small at presecretory stage (Fig. 4), whereas during the anthesis it grows much longer (Fig. 5). The epidermal cells of the ovary surface are nearby polygonal in outline having a strong relief (Fig. 6). Stomata, however, in the ovary epidermis are absent, probably due to the small dimensions of the organ. The six fertile androecial members of the perianth (stamens) are organized in to two whorls $(3+3)$ and are free of each other. The outer line of stamens is slightly shorter than the inner one. The bases of the yellowish green filaments are wide and coalesce to form a cavity where nectar accumulates. The six conspicously long stamens have orange anthers which produce large amounts of orange pollen. Stamens accrete with the basal part of the abaxial surface of filaments with the tepals of perianth. 


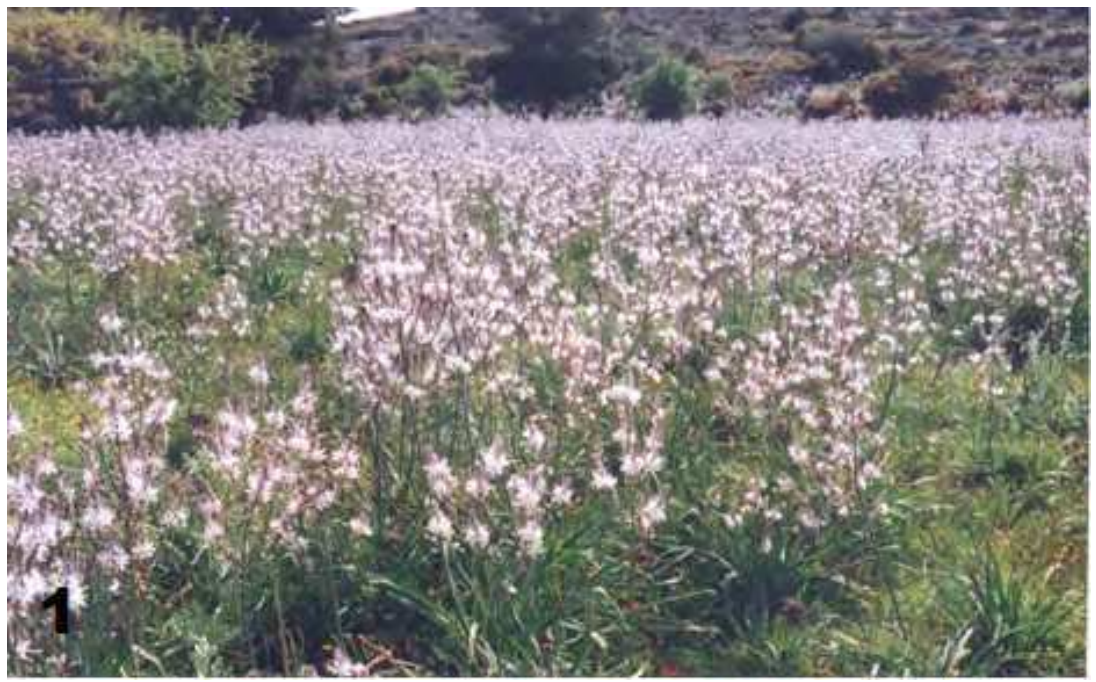

Fig. 1. Asphodel semi-desert in Thessaly, Greece.

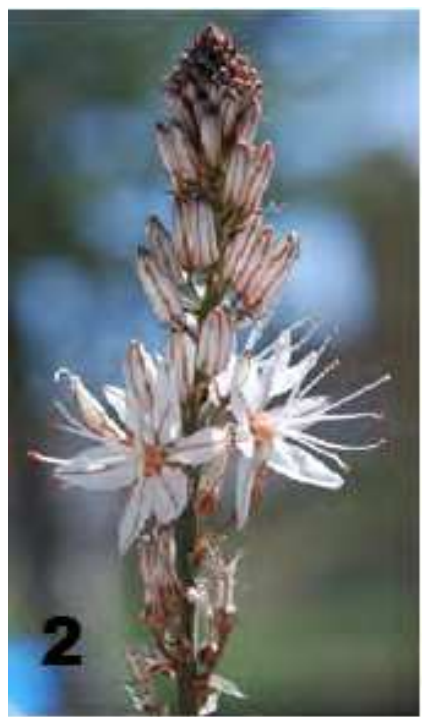

Fig. 2. Open flowers of Asphodelus aestivus consisting of six elongated petals. The flowers above bloom one by one.

\subsection{The nectary}

In cross section of the syncarpous gynoecium, the three carpels appear separated from each other by distinct septal slits. In these slits the tripartite floral nectary situated in the lower and middle part of the ovary (Fig. 7). The three septal slits proceed downwards entering the ascidiate zone of the carpels. The cavities are lined with secretory tissue which created 


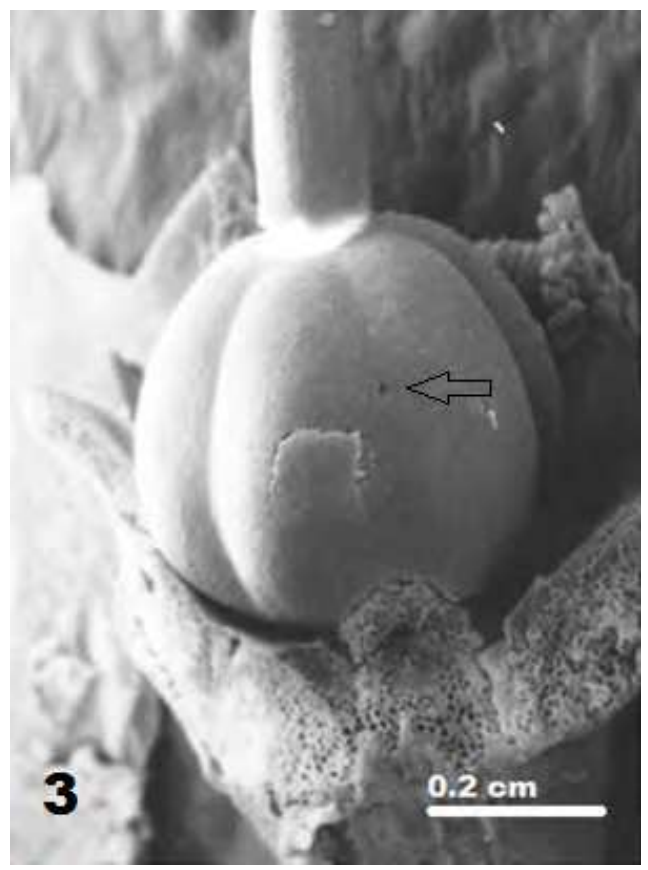

Fig. 3. Ovary formed by fusion of three carpels (syncarpous gynoecium). A narrow hole in the middle of the ovary (arrow) leading outwards the septal slid, X100.

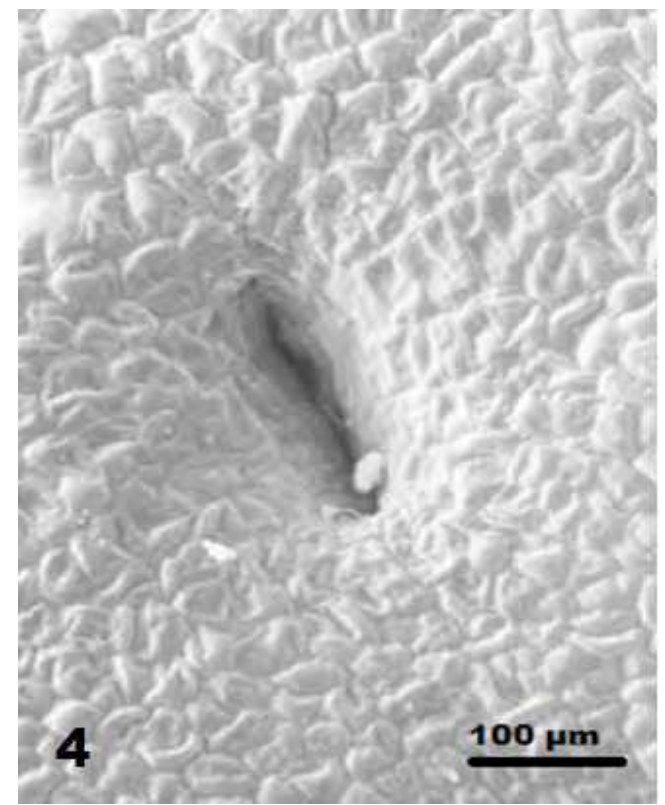

Fig. 4. Higher magnification of a small ovary hole at the initial development stages. 


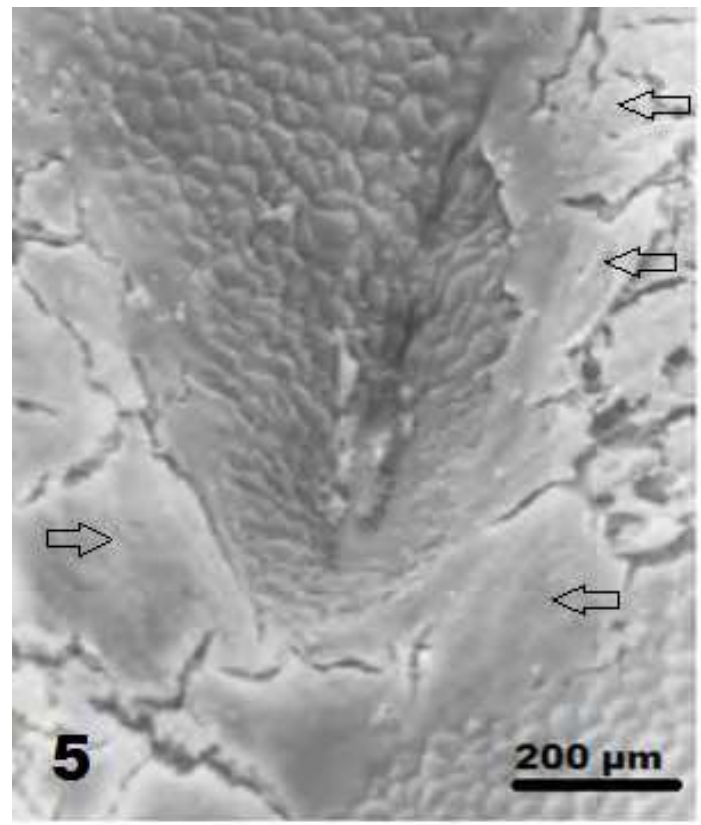

Fig. 5. Large nectary outlet at post secretory stage. Remnants of nectar are visible (arrows).

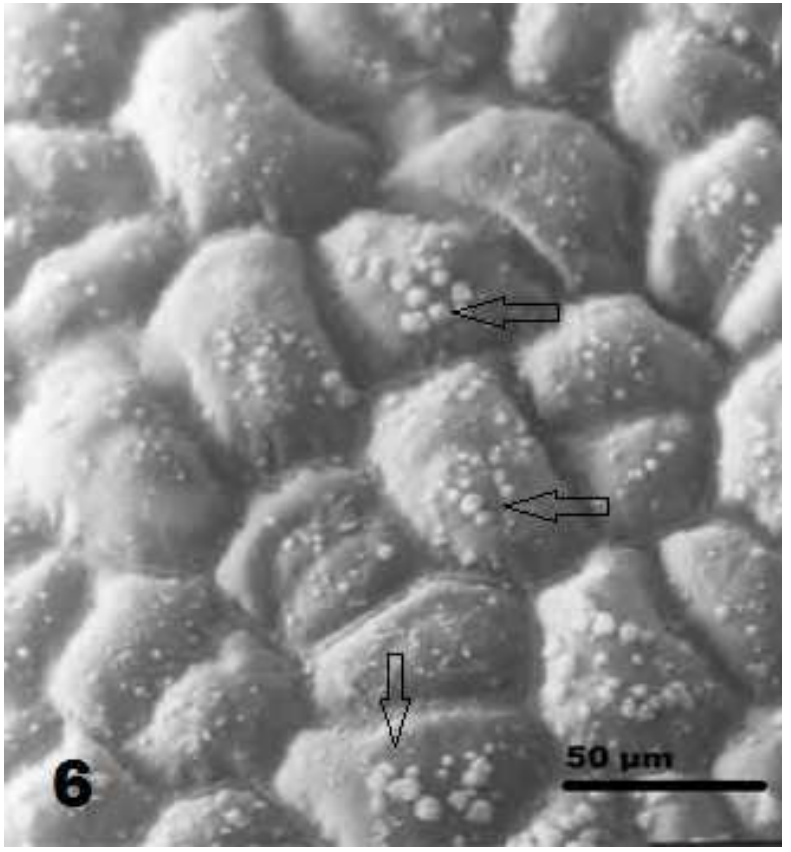

Fig. 6. Ovary epidermis surface with remnants of nectar (arrows). Stomata are absent. 
1-3 layers of the nectary epithelium. Each layer of epithelium consists of palisade or polygonal cells closely adpressed to the next ones. Epithelium cells of septal nectary are elongated and have very thin walls (Fig. 8). In the epithelium layer, stomata are absent and the cuticle lining the secretory cells is uniformly thin and electron opaque. In the nectariferous slits, at the initial development stages (pre-anthesis) structures like cytoplasmatic remnants are observed (Fig. 9), which may evidence lysigenous ontogeny of septal slits. Later, during the secretory stage, the nectar secreted by the epithelial cells accumulates in a space between the fusioned ovary carpels (slits).

At the beginning of anthesis (pre-secretory stage), the nectariferous tissue is well differentiated. The epithelium cells are more deeply stained than the surrounding subglandular parenchyma cells, containing a large, centrally situated nucleus and numerous organelles within a granular cytoplasm (Figs. 7,8 ). The variously shaped plastids contain osmiophilic stroma, peripherally located thylacoids and different sized starch grains. The vacuoles are poorly developed in contrast to the subglandular tissue cells. The reduction of vacuome and a considerable increase of ER in epithelial cells characterize this stage. During anthesis (secretory stage) ER cisternae are widespread in epithelial cells, occupying a considerable fraction of the cell volume. At the stage of maximal development, the secretory epithelial cells contain a great number of mitochondria and Golgi bodies. The ER is well developed and occurs as long strands of parallel cisternae (Fig. 11). Active cisternal profiles of ER, in close contact with plastids dominate the secretory epithelium (Fig. 12).

At this time, the cavities (slits) in the middle part of the septal region between two adjacent carpels are narrow and a flockular substance, possibly nectar, is observed in the septal slits (Fig. 10). In some places, this substance is surrounded by a thin layer of cuticle and separated cuticle fragments are visible inside the slit of the nectar. The nectar is released to the outside through the outlets (holes) in the middle of the ovary (Figs. 3-5). Nectar secretion leads to an expansion of the space between the septa. At the post-secretory stage (two days after anthesis), the secretory cells of the nectary appear to have large vacuoles occupying the greatest cell volume, many of which contain electron dense bodies. This stage is characterized by completely hydrolyzed starch, as well as disappearance of the amyloplasts and ER. Remnants of the nectar on the adjacent of the outlets surface of the ovary have been observed.

\subsection{The sub-glandular tissue}

The nectary is supported by the subglandular tissue, which consists of about 10 layers of relatively large, isodiametric parenchyma cells, with large vacuoles and nuclei, as well as many plastids. In the subglandular tissue, unmodified, thin-walled crystalliferous idioblasts containing raphide bundles are present among ordinary parenchymatic cells. These crystals are developed and stored rather passively within larger vacuoles of the specialised idioblast with a well distinctive tonoplast. Raphides appear in packs and wide morphological variations are observed among the cross sections (Figs. 13-15). Some electron dense substances penetrate the raphide surface and raphide grooves. Raphides form in bundles of narrow, elongated needle-shaped calcium oxalate crystals, usually of similar orientation, with pointed ends at maturity, in idioblast cells. 


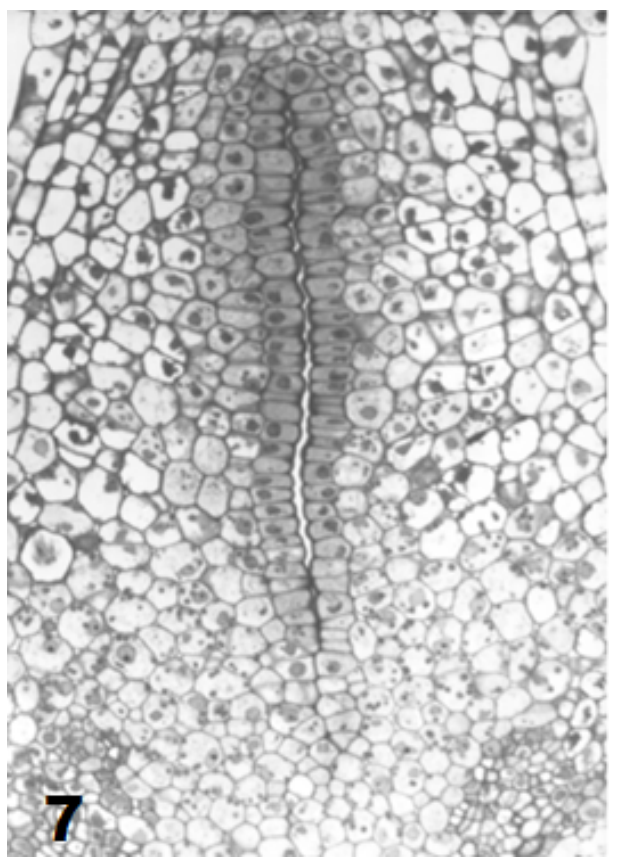

Fig. 7. An ovary carpel containing a septal nectary X 120 .

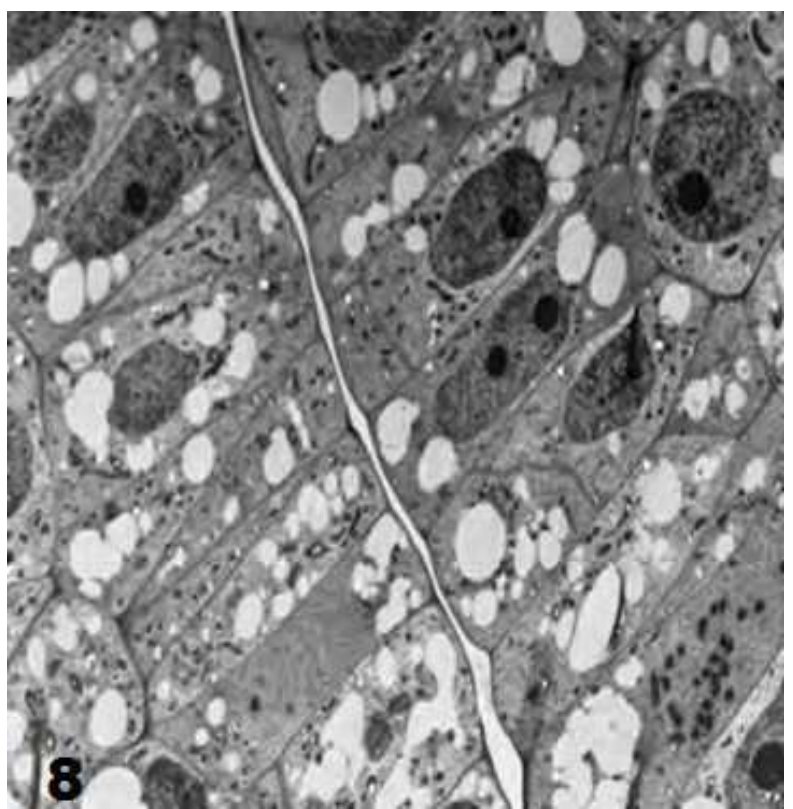

Fig. 8. Septal slit developed in nectary. The epidermal cells of the carpels contain dense cytoplasm and a large nuclei X 3.000 . 


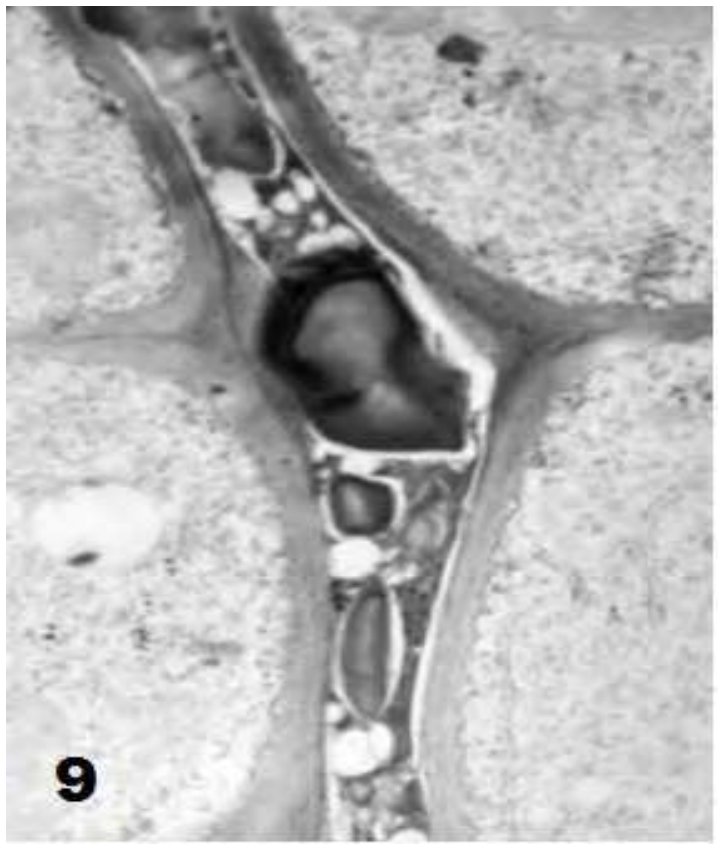

Fig. 9. Visible cytoplasmic remnants within the nectary slit X 20.000.

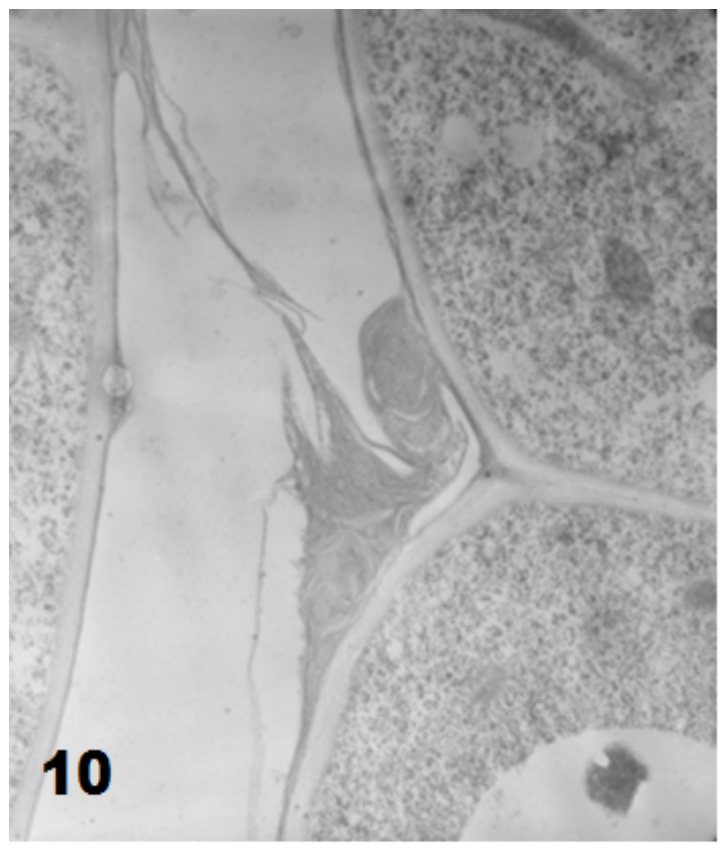

Fig. 10. Flockular substance, obviously nectar within the nectar slit X 20.000. 


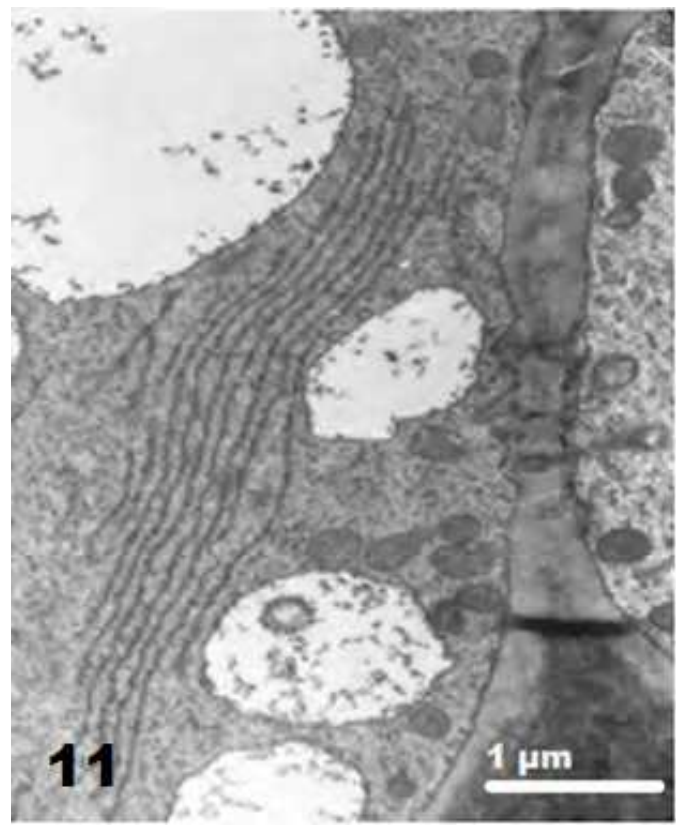

Fig. 11. ER occurring in strands of four or six cisternae at the lower part of the epidermal cell $X$ 20.000. A number of plasmodesmata connecting the epidermal cells to subglandular tissue.

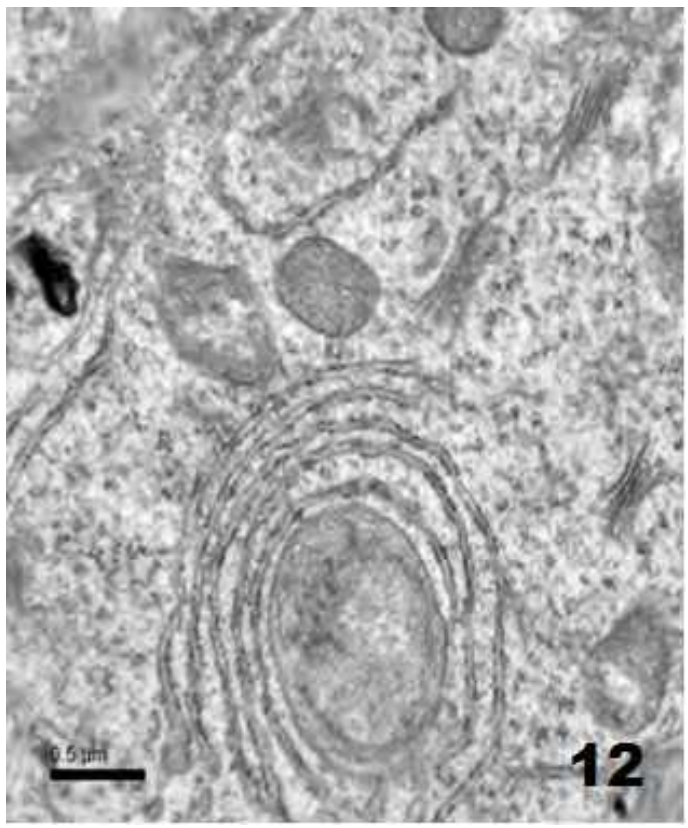

Fig. 12. Dictyosomes and ER cisternae in close contact with plastids. 

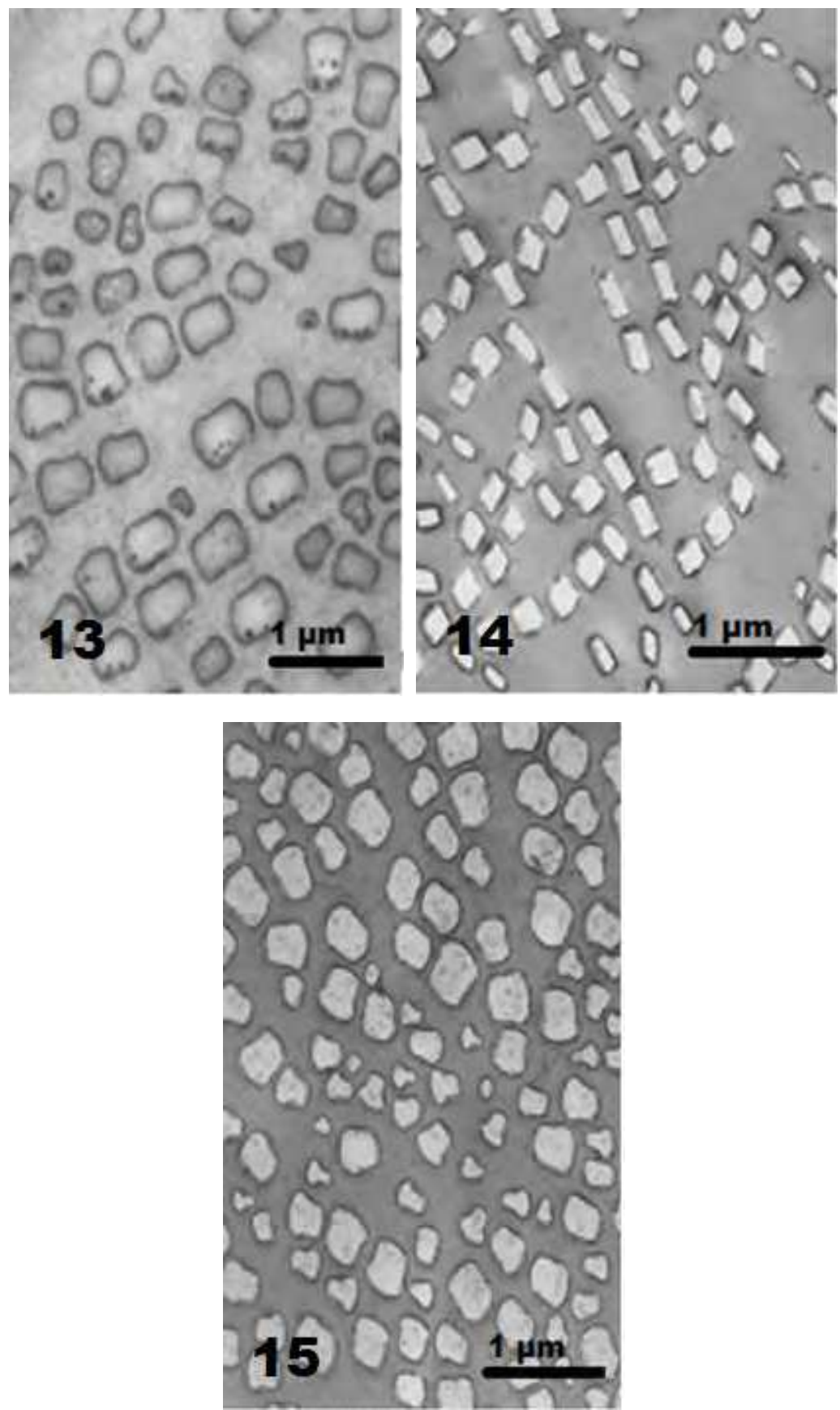

Fig. 13. - 15. Cross-sections of raphide crystals from parenchymatic subglandular tissue appeared in packs and wide morphological variations. 

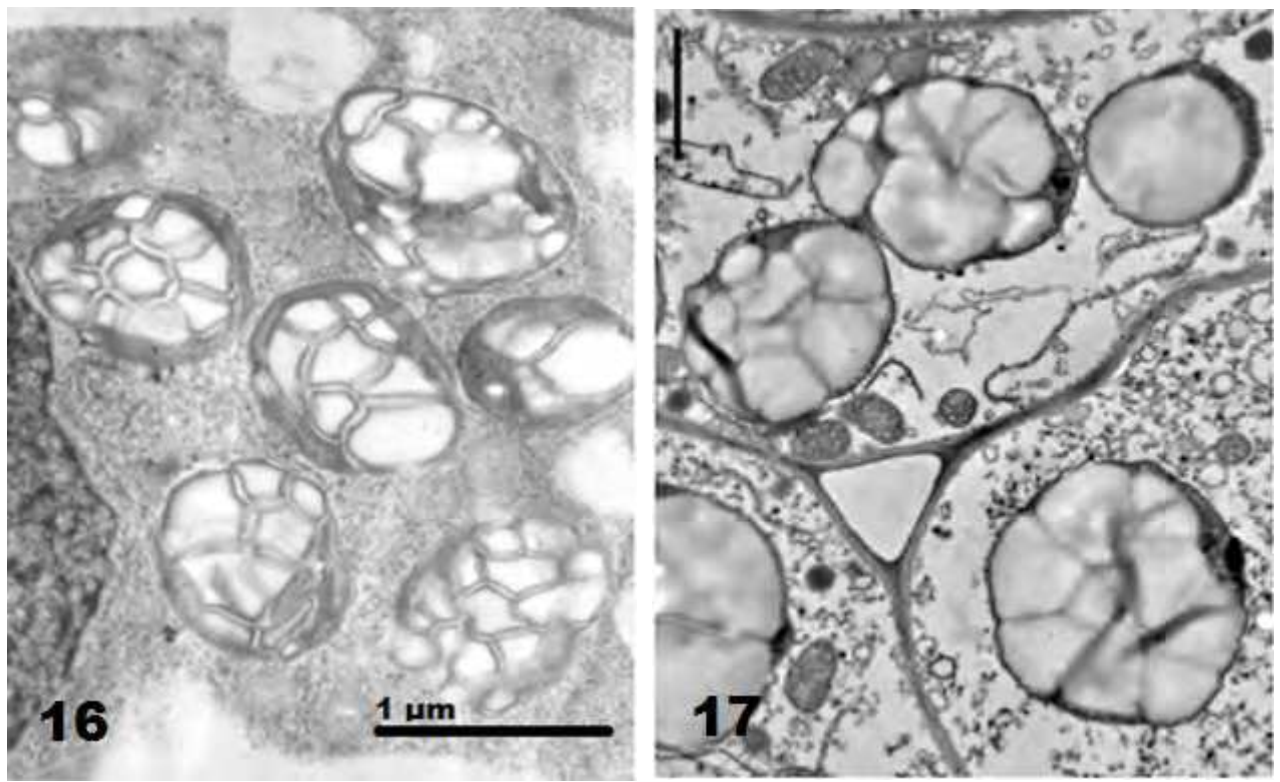

Fig. 16. - 17. Large starch grains in plastids of subglandular cells under the nectary (Fig. 16) and under the obturator (Fig. 17), at the initial developmental stages.

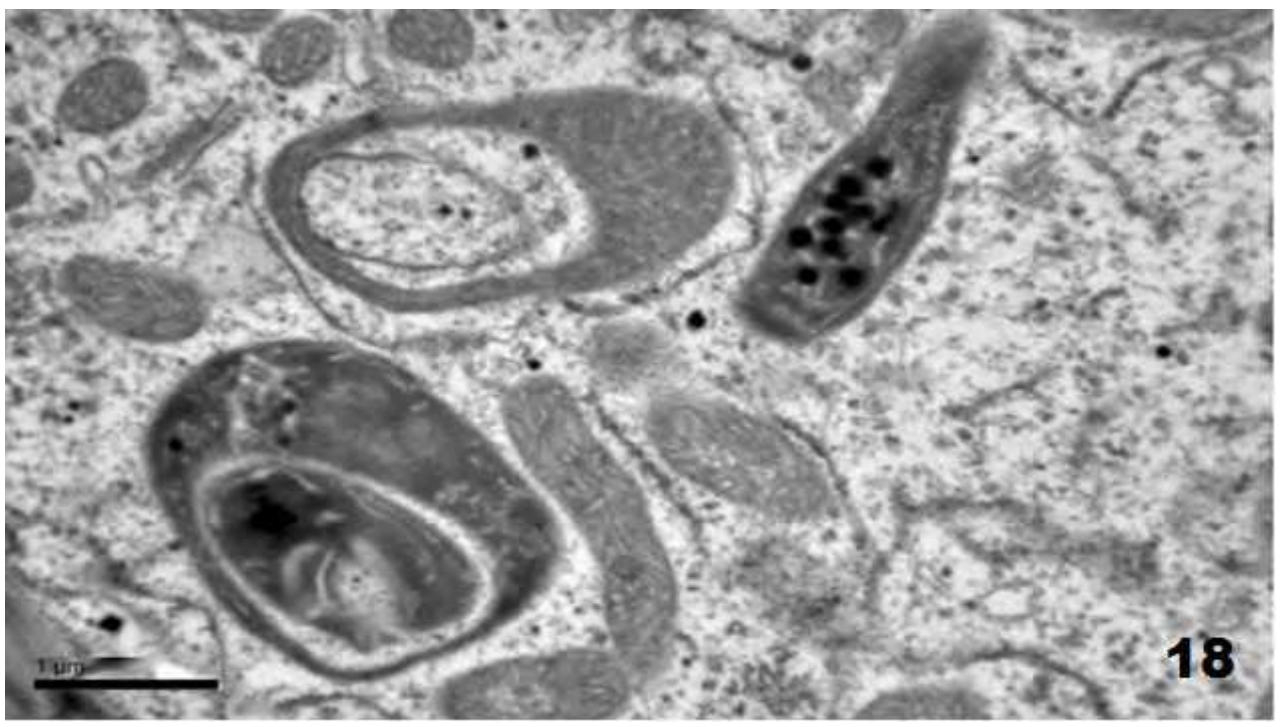

Fig. 18. Variously shaped plastids containing osmiophilic stroma without starch, after the secretory stage.

At the initial developmental stages of the nectar, enormous starch grains occur in cells of the subglandular tissue of various shapes and different sizes (Figs. 16, 17). Later, during nectar 
secretion, starch content drastically diminishes from the nectar epithelium towards the peripheral cells (Fig. 18). The use of Schiff's reagent allowed the exact location of starch in examined tissues (Figs. 19-21). At the beginning of the anthesis starch grains occur mainly in subglandular tissue cells. At this time, in epithelial, starch grains occurr sporadically and they are much smaller than in the subglandular parenchyma cells. Intercellular spaces of the subglandular tissue are very large and the parenchyma cells are connected to the nectary cells with plasmodesmata grouped in pit fields (Fig. 11). The nectary is supplied directly with well-developed vascular tissue, innervated exclusively by phloem strands. Xylem components are also noted in subglandular parenchyma.

\subsection{The obturator}

In the ovary of A. aestivus there are several ovules per carpel and placentation is axile. Between the lateral ovule and the ovary septa a central protrusion develops into a gland, the obturator. This is a prominent ovary wall outgrowth of placental origin, which lies in close contact with the micropyle of each ovule. The obturator is a secretory structure (mucilage gland), which gives a weak reaction (after employing the Schiff's reagent) at the initial developmental stages when starch the grains of the parenchyma cells are intensively red (Fig. 20). Later, during pollination, when starch has disappeared from the plastids, the presence of cells with a polysaccharidic content is more intense (Fig. 21). Starch stored within amyloplasts can be used both as a source of energy for highly metabolic processes and as a source of mucilage production. In the secretory cells of the obturator, numerous cisternal elements of ER in parallel arrangement are widespread occupying a considerable fraction of cell volume (Fig. 23). Numerous vacuoles containing amorphous electron dense material and mitochondria appear. Among ER cisternae, large vesicles with granular content occur. Golgi bodies are also prominent and consist of stacks of three to four cisternae.
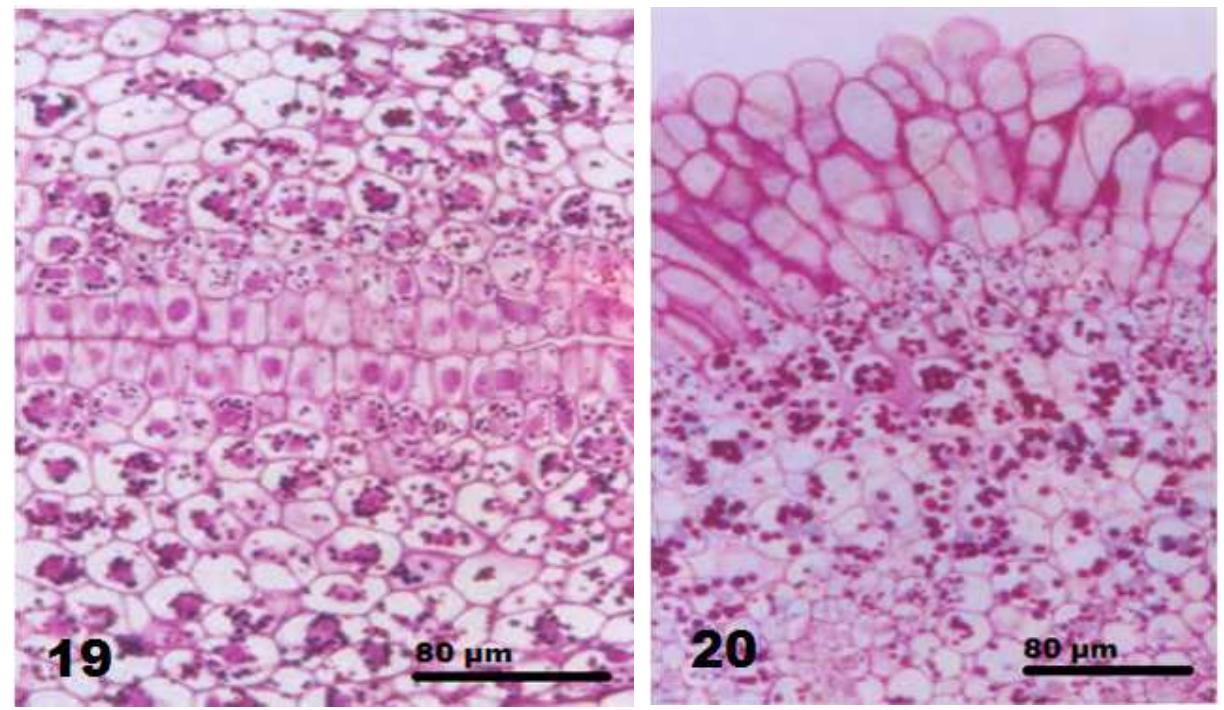

Fig. 19. - 20. Plastid starch grains from the nectary (fig. 19) and obturator (Fig. 20) subglandular tissue stained with the Schiff's reagent at the time before nectar secretion. 


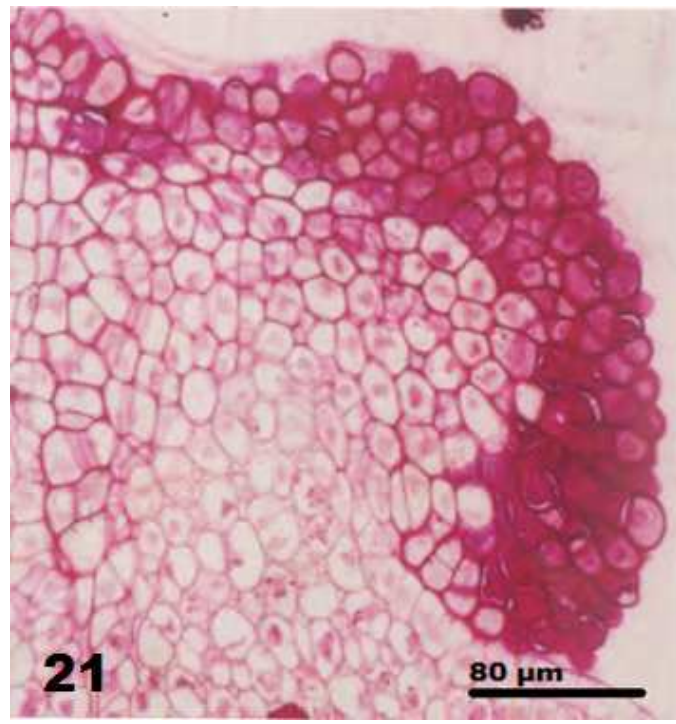

Fig. 21. Intense staining of the obturator papillae at the time after the nectar secretion. Plastid starch is completely absent from the subglandular tissue in comparison to Figs. 19 and 20.
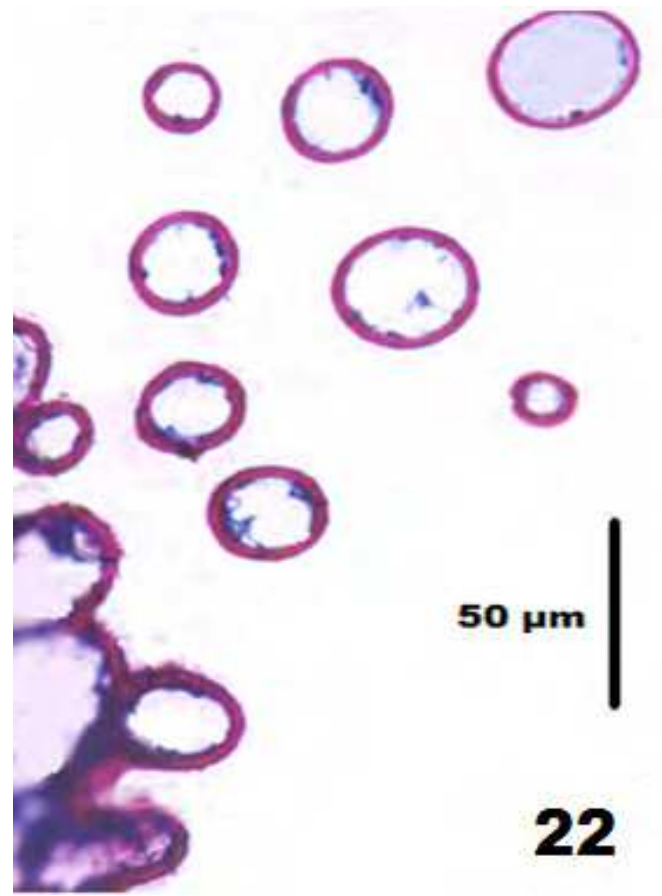

Fig. 22. Cross section of osmophore papillae at the bottom of the perianth tube. Cell walls stained red with the Schiff's reagent. 
Mucilage is usually secreted by the Golgi apparatus and becomes processed by the ER (mucoprotein). The cells of the gland are internally surrounded by an extraplasmic space filled with the mucilage. Many dictyosomes with large vesicles at the ends of the cisternae and prominent ER elements reveal a secretory activity. Golgi bodies become associated with ER elements and bud off vesicles with a mucoproteinaceous content. The vesicles subsequently move to cell periphery, fuse with the plasmalemma and release their contents into the extraplasmic space between cell wall and plasmalemma.

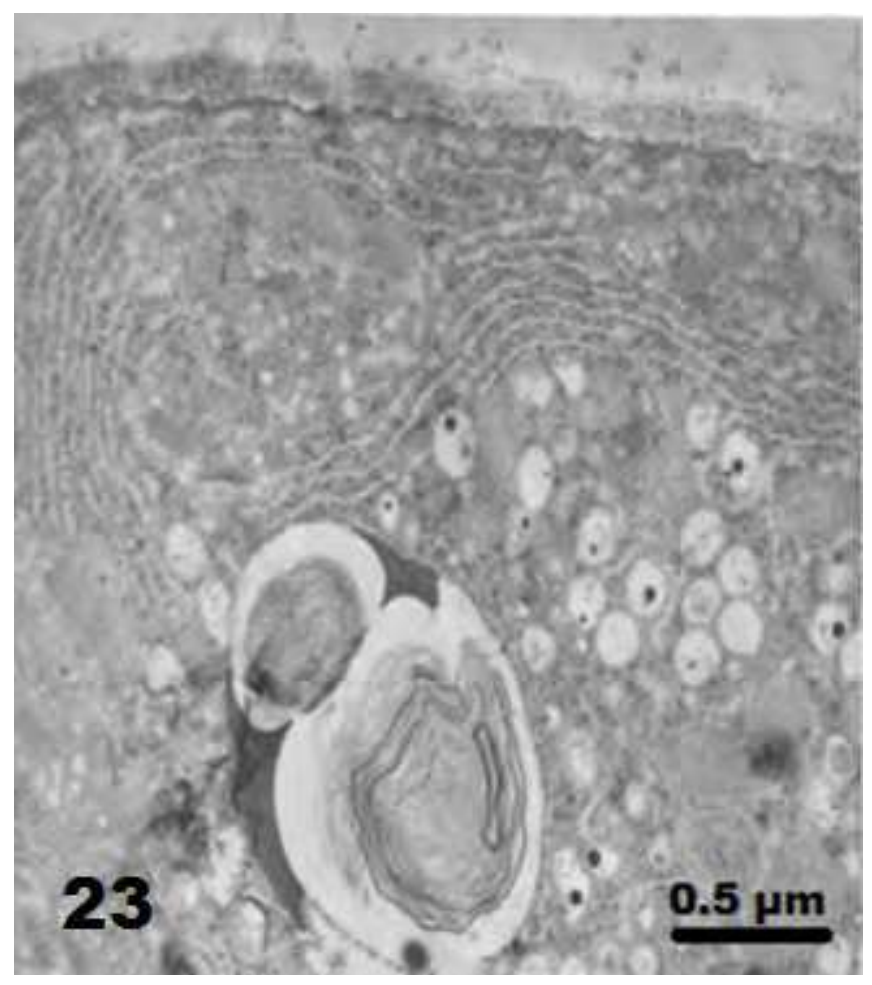

Fig. 23. Tip region of obturator papillae cell. ER cisternae occupying a considerable fraction of cell volume. Vacuoles of relative small size containing electron dence globules. Myelin like structures are also common.

This space progressively increases in volume towards the centre of the secretory cells at the expense of the protoplast (Fig. 24). In EM, mucilage can be detected after polysaccharide staining with the Thiery-reaction. A fine granular silver deposition reveales the fibrillar nature of the mucilage (Fig. 25). Silver deposits from the Thiery reaction are detected on the starch grains of amyloplasts in the subglandular parenchyma cells, whereas the rest of the amyloplast area appears completely negative to the reaction. In the cell wall silver grains are mostly deposited in the middle lamella consisting mainly of pectins (Fig. 26). 


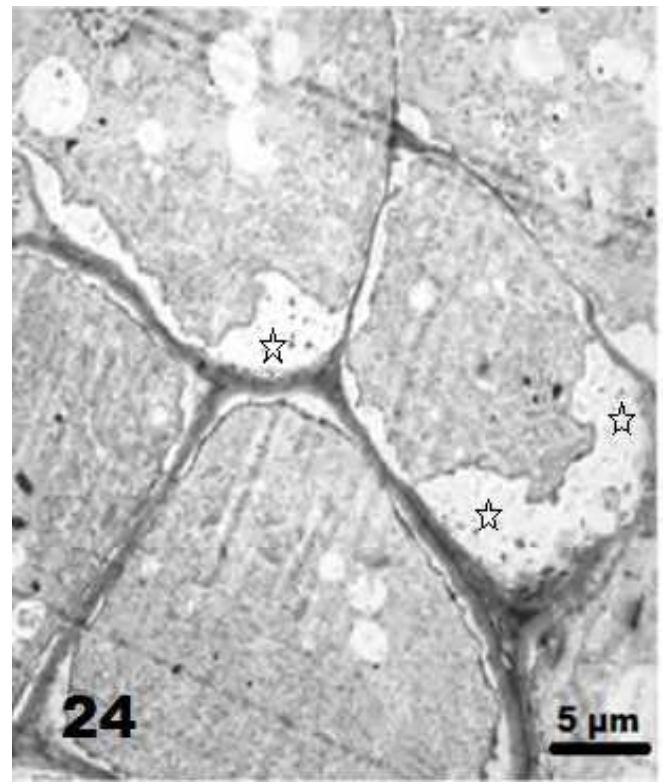

Fig. 24. Wall protuberances (asterisks) of the elongated papillae cells during the secretion process.

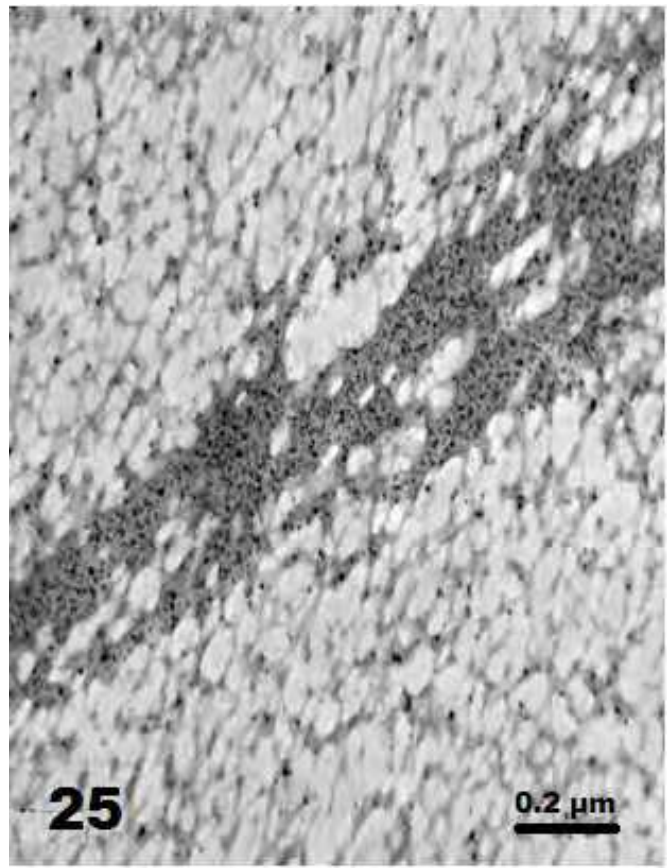

Fig. 25. Fibrillar mucilage material after polysaccharide staining with the Thiery-reaction. 


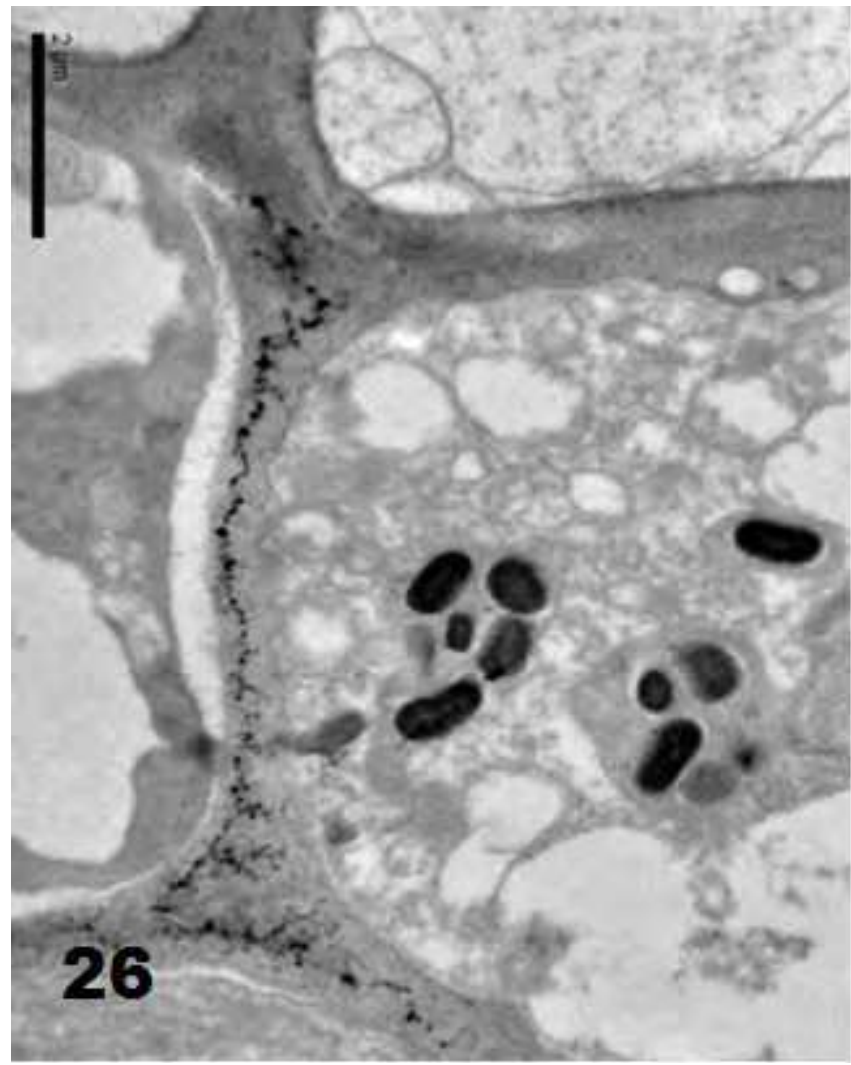

Fig. 26. Silver deposits on starch grains and the middle lamella of subglandular cells.

\subsection{The osmophores}

In $A$. aestivus flower the six, closely packed stamens surround the ovary in very close proximity to the nectar-releasing area. Their lower filament part is widened and flattened (Fig. 27), protecting the outlets of septal nectary. At this basal region of the stamen, the epidermal cells become larger and stretch outwards forming numerous papillose cells of various size and shape, the osmophores. The osmophores of A. aestivus are supported by subepidermal layers of parenchyma cells with large intercellular spaces (Fig. 27). In these subepidermal layers a well developed phloem is present. The centrally located vascular bundle is surrounded by closely layered parenchyma cells (Fig. 27). A feature also typical of osmophores is their intensive aeration by means of large intercellular spaces. In the cells of epithelium and subepidermal layers the presence of starch is also observed. The largest club-shape osmophores (approximately $170 \mu \mathrm{m}$ ), occur on the edges of the flattened part of filaments (Fig. 28). The outside, convex wall of the isodiametric papillose cells of the epidermis is considerably thick reaching on average $4.40 \mu \mathrm{m}$ (Fig. 29).

PAS reaction reveals that the cell wall derives from cellulose (Fig. 22), while treating with safranine does not indicate any presence of lignin (Fig. 30). Osmophores possess a large 
central vacuole whereas numerous small vacuoles are also present in the cytoplasm, which enlarge during the emission of secretion and divide the cytoplasm into characteristic net-like strips. On the longitudinal cross-sections the central part of the club shaped hairs and papillae are filled usually by one vacuole, around which there is the cytoplasm which creates a rather thin layer. In the cytoplasm, also small numerous vacuoles are observed (Fig. 30), which gradually increase in size. Significantly enlarged nuclei $(31 \mu \mathrm{m})$ in relation to the nuclei in the parenchyma $(12 \mu \mathrm{m})$ are usually located half way lengthwise in the clubshaped papillae. In the cytoplasm, numerous, small plastids are observed. On the basal part of filament osmophores are well developed in comparison to the above (Fig. 31), especially on the filament edges. On their surface the cuticle reveals a striped ornamentation (Fig. 33). On the top area of some of the papillose cells, round flattened areas are observed, which probably mark breaking of the cuticle after emission of the previously accumulated elicitor (Fig. 34). The cross-sections of the papillae have round or oval shapes (Fig. 22).

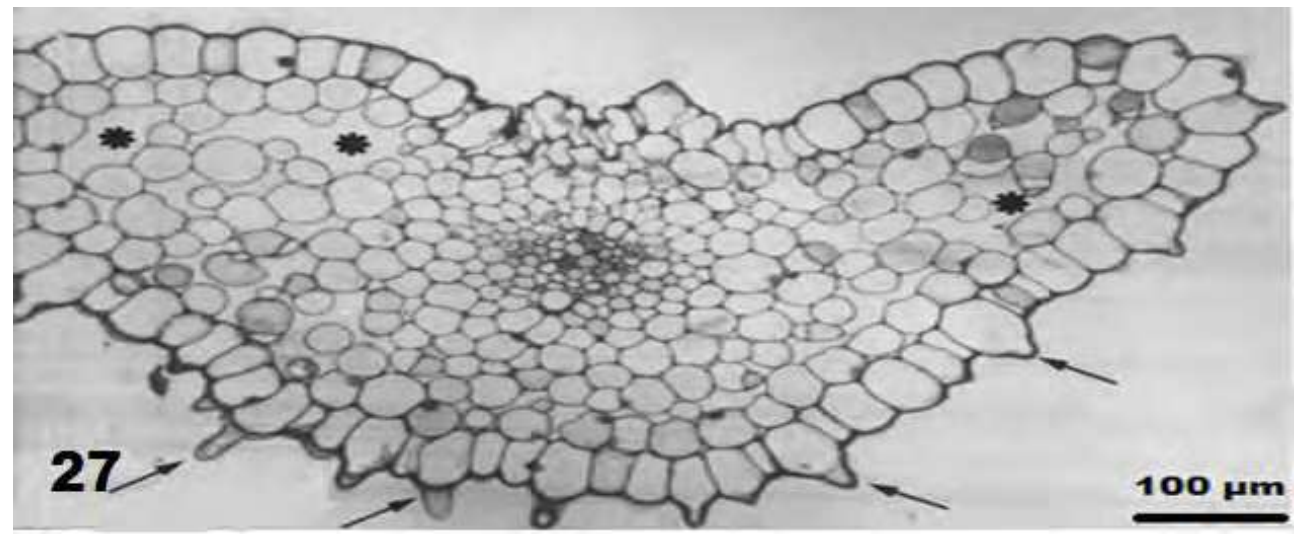

Fig. 27. Cross-section of the wider filament near the basis, bearing only one central vascular bound. Papillose cells (arrows) and large intercellular spaces (asterisks) are visible.

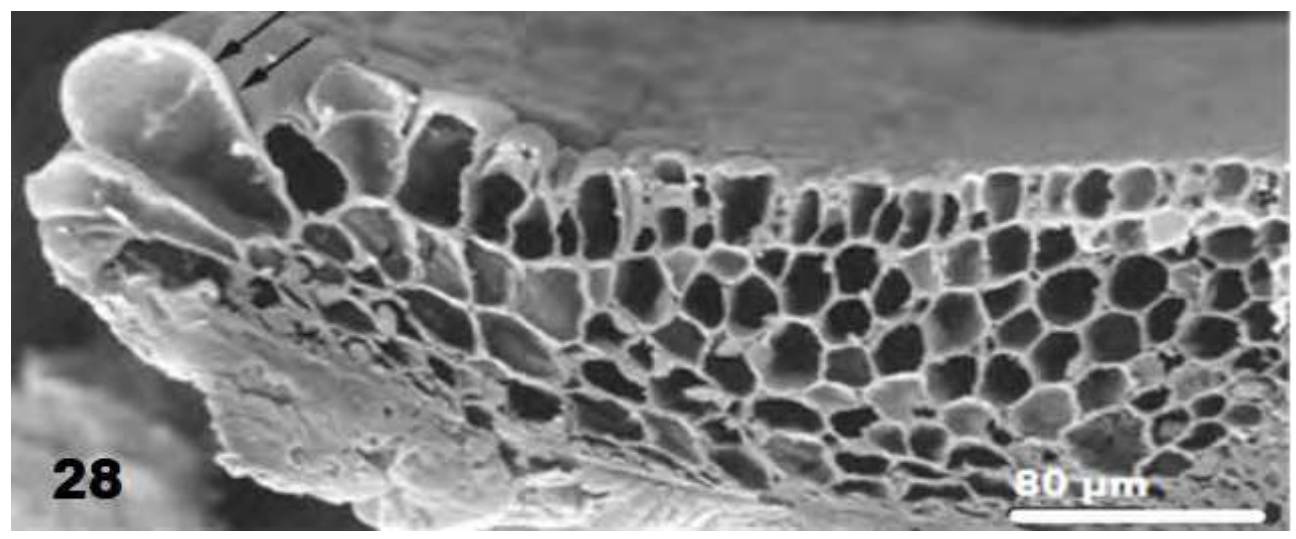

Fig. 28. SEM image of cross section at the lower part of filament forming at the edge unicellular osmophore papillae (arrows). 


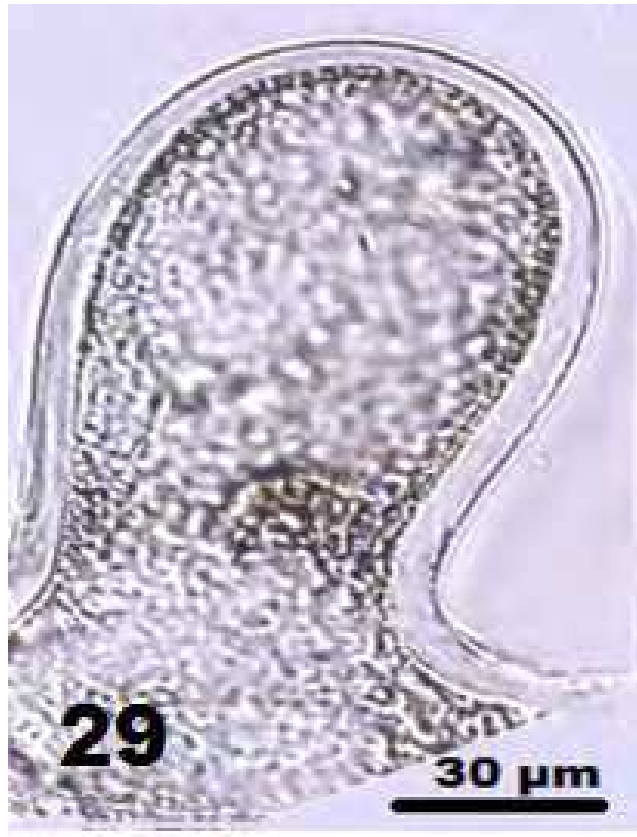

Fig. 29. Longitudinal section of osmophore papilla with thick cell wall.

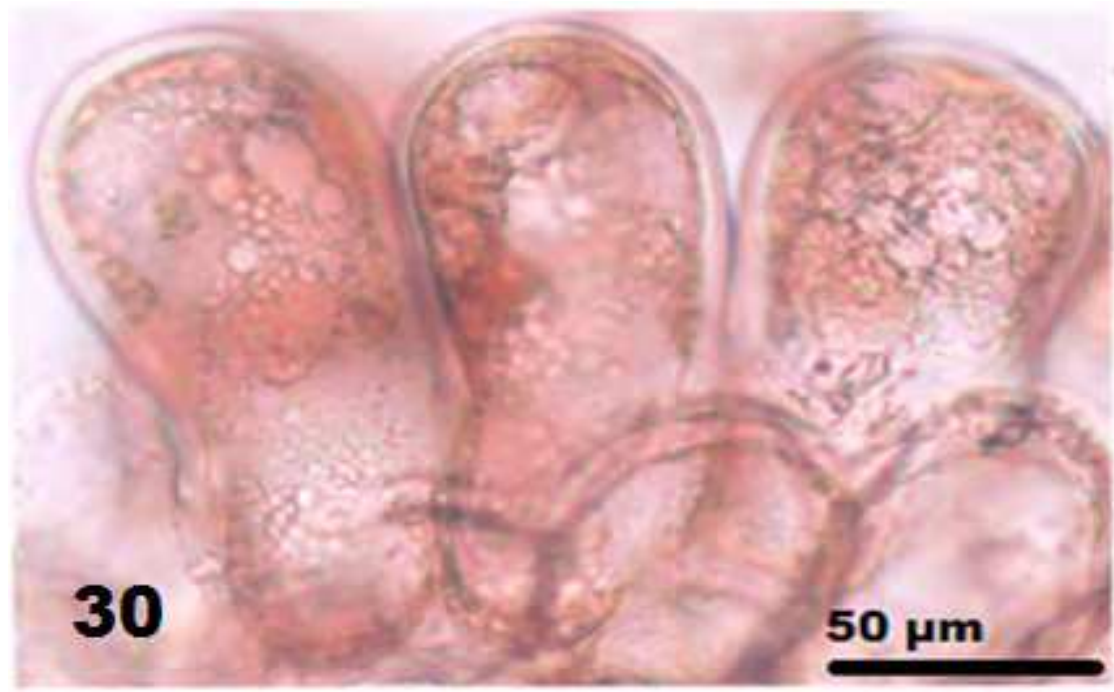

Fig. 30. Osmophores treated with safranin. Numerous small vacuoles in the cytoplasm. 


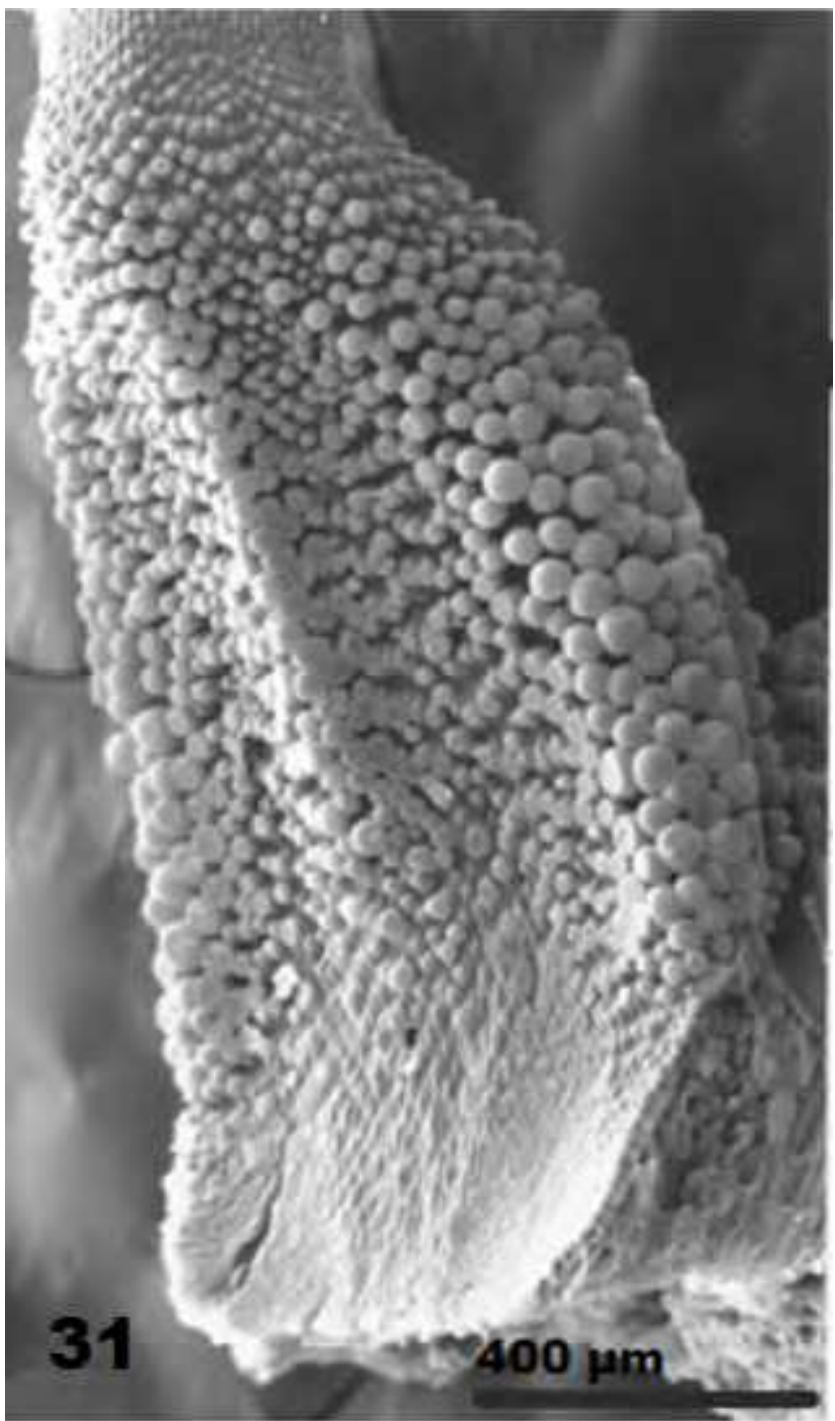

Fig. 31. Lower part of a filament with densely developed osmophores. 


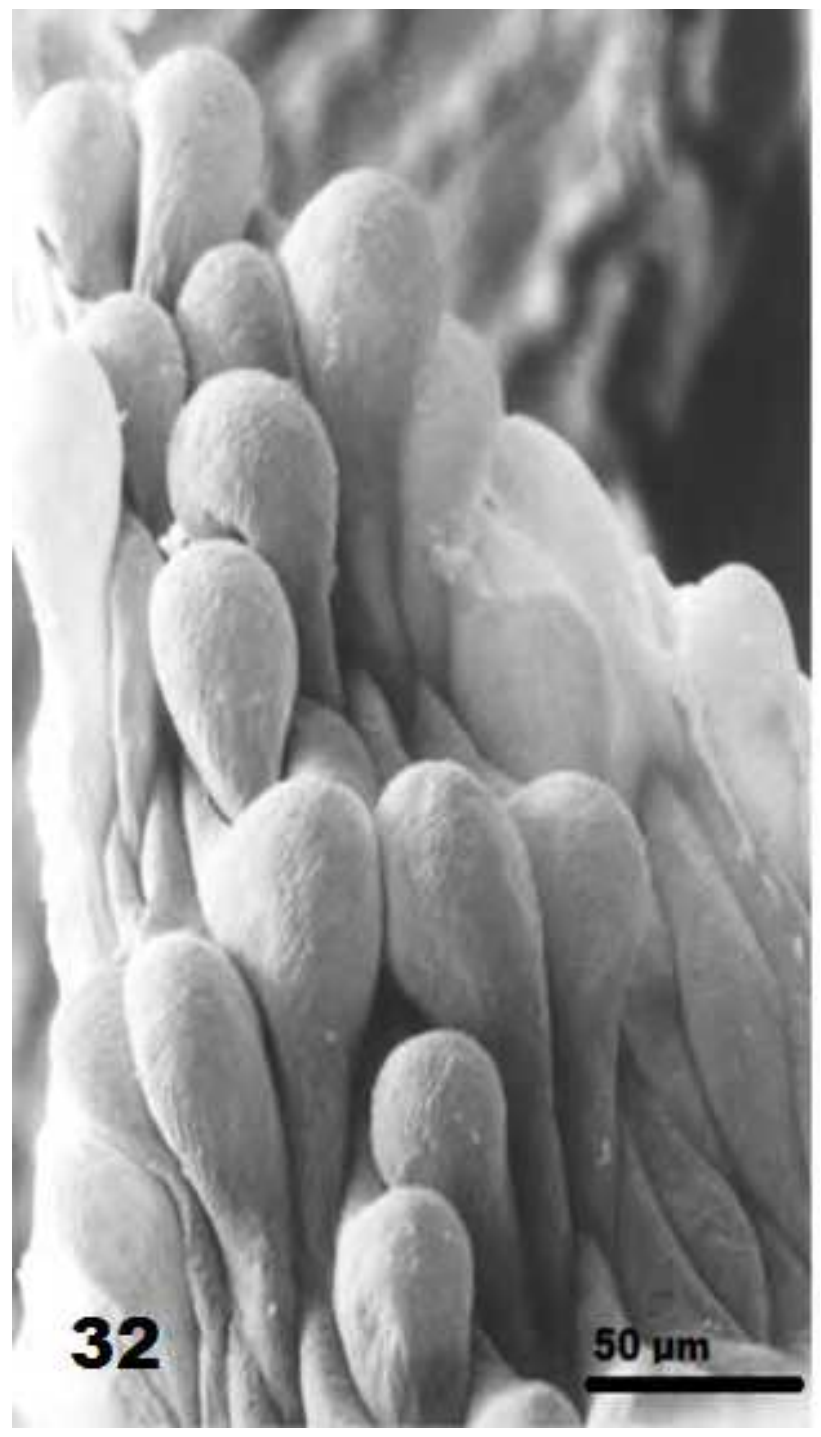

Fig. 32. Osmophore papillae near the filament basis. 


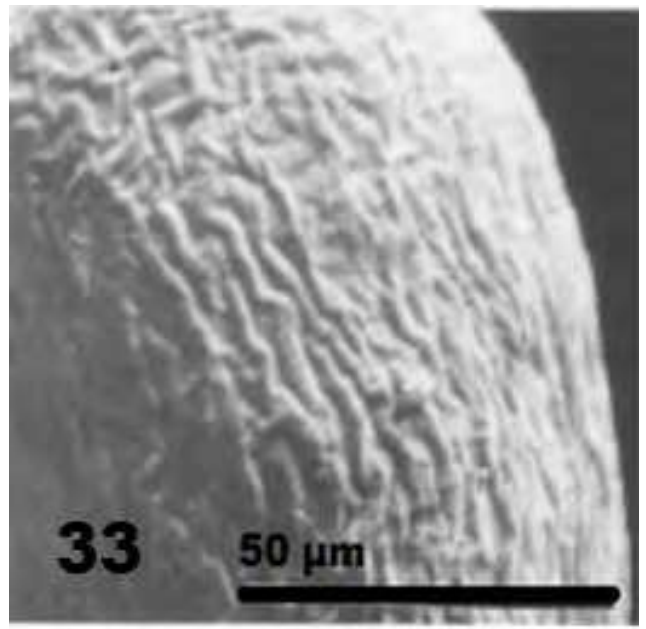

Fig. 33. Outer osmophore surface with irregular wrinkles.

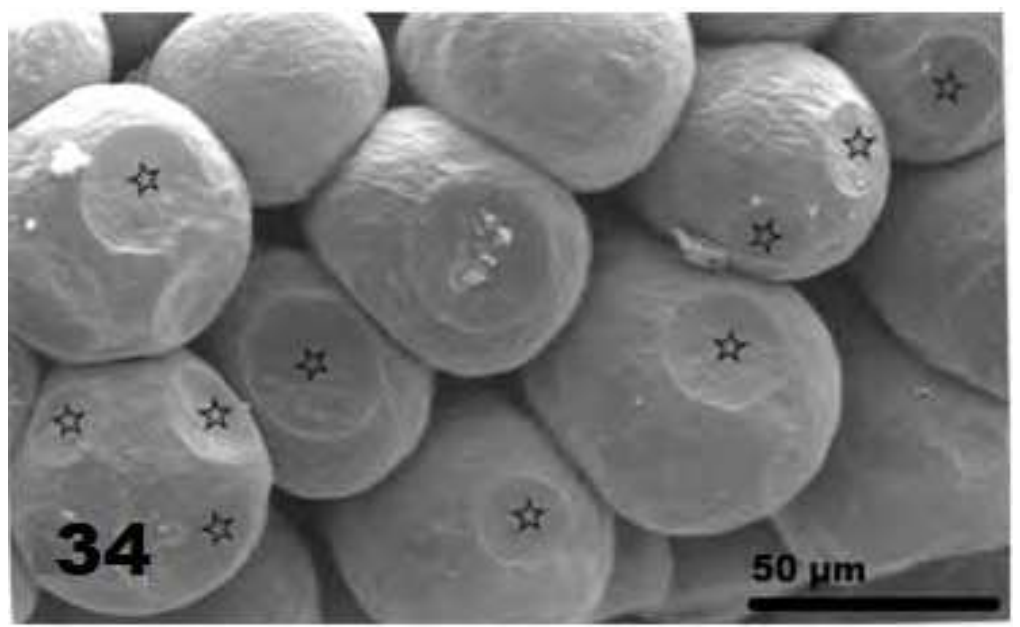

Fig. 34. Circular traces on osmophore surface (asterisks) after emission of secretion.

\section{Discussion}

\subsection{Nectar secretion and pollination}

The septal nectary of $A$. aestivus formed by the incomplete fusion of the carpel flanks and lined by a secretory epithelium is the most common type of nectary in monocots (Vogel, 1998; Staufer et al., 2002). Tripartite nectaries are located in septal slits and their outlets have the form of elongate grooves which are situated above the middle part of the ovary. Septal slits in A. aestivus nectary are surrounded by 1-3 layers of epithelial cells, whereas in other plants, mostly one layer of the nectariferous tissue occurrs in the septal nectaries (Weberling, 1992; Smets et al., 2000). Gynopleural septal nectaries are considered the most advanced in 
the philogenetical development of plants. Many studies show that the migration of nectary glands proceeds in flowers from the perianth to internally located organs (Esau, 1965).

In $A$. aestivus nectaries, the epidermis of the septal slits participates in nectar secretion, since stomata in the nectary epidermis or on the ovary surface are absent. This fact agrees with the statement of Endress (1995) that nectarostomata are usually absent from monocotyledons. The side of the septal nectaries is diverse in the ovary in different representatives of monocotyledons. In some taxa, nectaries are situated at the base of the ovary with the outlet in the same region - Johnsonia, Lomandra, Tofieldia (Smets et al., 2000). In other genera, the nectar occupies the septal slits only in the upper part of the ovary with the outlet near the style base Haemanthus, Astelia, Yucca (Smets et al., 2000), Haworthia and Gladiolus (Weberling, 1992) and Acidanthera (Weryszko-Chmielewska et al., 2003). For Allium (Alliaceae) Maurizio and Grafl (1969) described the distribution of the opening of septal nectar at the half of the ovary height. This location is similar to the position of the outlets of the A. aestivus nectar (Weryszko et al. 2006).

Flowers of all species of Asphodelus are very attractive to pollinators since they produce large amounts of nectar (Cruden, 1977; Diaz Lifante, 1996). Some environmental factors, like drought, may affect the amount and viscosity of nectar influencing the visiting of pollinators (Harder, 1986). Changes of the nectary color provide insects with a signal that no reward is offered by a particular flower, thus forcing the insect to seek reward elsewhere. The maximum offer takes place during the morning, in a day of normal activity of insect visitors. The "large bee-dish shaped blossom" morphology of the A. aestivus flowers, as defined by Kugler (1977), allows the access of insects of a very wide range of size. The nectar is released to the outside through small holes on the ovary walls and accumulates in the base of the perianth tube. The accumulated fluid is retained until removed by a foraging insect. Ravena (2000) suggests that, in addition to the insect-like flowers, nectar derived from septal nectaries may be a further attraction to insect pollination. On the other hand, absence of nectar often indicates an alternative pollination mode (Rudal et al., 2002). Strong or distructive floral scents are associated with pollinator attraction (Hadacek and Weber, 2002; Effmert et al. 2005).

\subsection{Obturator and fertilization}

One of the secretory structures of the A. aestivus flower, connected with the process of fertilization, is the obturator. This is a mucilage gland, located between the lateral ovule and the ovary septa. The obturator is a placental protuberance at the ovary entrance connecting the transmitting tissue with the ovarian cavity (Tilton \& Horner, 1980; Tilton et al., 1984; Herrero, 1992). The obturator acts a drawbridge, connecting the base of the style with the ovule. It contributes to the fertilization process by secreting different components involved in the growth of the pollen tubes just before they penetrate the micropyle (Tilton et al., 1984; Cheung, 1996). The obturator secretes a mucoproteinaceous product and gives a positive reaction after employing the Schiff's reagent. In spite of the early description of the obturator and its observation in a number of unrelated species very little is known about its function (Tilton \& Horner, 1980; Herrero, 2000). Obturator invariably appears to support pollen tube growth on its way to the ovule, and it represents a further adaptation of a secretory placenta. By forming a little protuberance, it bridges the gap between the placenta and the ovule entrance, thereby facilitating the passage of the pollen tube in its journey 
towards the ovule, but only for a defined period, and at a specific stage of development (Herrero, 2003).

Pollen tubes first stop at the obturator, which lines the pollen tube pathway towards the ovule (Herrero, 2000). The pollen tubes are arrested at the obturator for a number of days until this structure enters a secretory phase accompanied by the vanishing of starch and accumulation of callose in the obturator (Arbeloa \& Herrero, 1987). Pollen tubes must grow through the mucilage-filled intercellular spaces across the obturator before reaching the micropyle of the ovule (Webb \& Williams, 1988; Clifford \& Sedgley, 1993; Ciampolini et al., 1995; Weber \& Frosch, 1995; Cheung, 1996). When the pollen tube arrives at the obturator the cells of the obturator surface are full of starch and devoid of secretion. Pollen tube growth is only resumed concomitantly with the production of this secretion providing nourishment for the growing pollen tubes. At the stage when the gland becomes functionally active in mucilage secretion entering the secretory phase the pollen tubes travel swiftly over this structure and enter the ovule (Gonzalez et al., 1996). The above pattern of secretion has been also observed in other mucilage glands (Lynch \& Staechelin, 1995; Western et al., 2000).

\subsection{Secretion mechanism}

As to the manner of cellular secretion, the general literary consideration is that the type of granulocrine secretion is characterized by an abudance of active ER, mitochondria and Golgi. Eccrine secretion is characterized by relative few ER and Golgi but numerous plastids containing starch grains (Fahn, 1990). In the nectary of A. aestivus, the activity of the extensive ER, the number of mitochondria and the presence of vesicles in the Golgi cisternae suggest that granulocrine secretion is the mode of transport of nectar in this species (Rachmilevitz \& Fahn, 1973; Fahn, 1979). Few starch grains are present in the nectariferous cells of A. aestivus, a fact implying that starch reserves contribute little to the nectar secreted. It is also suggested that the mode of nectar secretion from the nectariferous cells is granulocrine although further research is needed to confirm this hypothesis. Based on features of the ultrastructure of glandular cells it can be determined which pathway of nectar transport from inside to the outside of the nectariferous cells occurs.

The vascular tissue occurring in the subglandular parenchyma might serve the nectaries supplying them with carbohydrates. The bulk of nectar precursors come from the subglandular parenchymatic tissue and the phloem of the vascular bundles. Nectar secretion from the epithelial cells of the $A$. aestivus nectary slit takes place through a relatively thin cellulose wall. Nectar collects outside between the wall and the bulging layer of the cuticle, which then bursts, causing the release of nectar. After the nectar slit is filled up to about half of the height of the ovary, where the outlet of the nectary is situated, nectar flows outside and stops on expanded parts of filaments and perianth tepals. In A. aestivus, nectar production is supported by carbohydrate storing at the below-ground parts, since root tuber content of starch, lipids and soluble sugars varies considerably over the year (Sawidis et al., 2005).

Polysaccharides as well as total sugar contents are always higher in root tubers than in leaves. The highest values of soluble sugars appear in root tubers, in late spring-early summer. Since the $A$. aestivus root tuber biomass is 6- to 30 -fold higher than that of the above ground plant parts (Pantis, 1993), this leads to the conclusion that the below ground 
part consists of a rather stable energy reserve under continuous replenishment. The greatest percentage of allocated biomass and nutrients is located in the tubers during the whole year. The nectar production is supported by stores in the below-ground parts. Hence, the changes of below- and above-ground biomass reflect adaptations, which synchronize the plant's phenological development with the seasonality of the Mediterranean climate. This seems to hold also in the case of $A$. aestivus, which has to withstand summer water stress in the semiarid Mediterranean ecosystems. The deposition of nutrients allocated to root tubers of A.aestivus are highly variable, which is characteristic of plants living in unstable habitats (Muller, 1979), such as the asphodel semi-deserts. Changes in the contents of these compounds in the root tuber tissues suggest a massive translocation of soluble sugars over a year period (Meletiou-Christou et al., 1992).

\subsection{Raphides and defence}

Calcium oxalate needles in subglandular tissue are typical of raphide bundles found in other organs of $A$. aestivus. Isolated thin-walled crystalliferous idioblasts also occur in the root tubers where a greater variation of morphological differences of raphide cross sections is observed (Sawidis et al. 2005). Such morphological differences of raphides could potentially influence the degree of acridity. In parenchyma tissues the need for fight herbivores seem to be more vital. Irritation is both mechanical and chemical. When raphides come into contact with the tender tissues of worms and other herbivores these substances are injected, enter the wounds causing a traumatic injury and inflammation. This defense task, undertaken among others by raphides, seems to be vital to the parenchymatous subglandular tissue. The protection of $A$. aestivus raphides against herbivore attacks is reinforced by other cells containing defense compounds, such as alkaloids, found in other parenchymatic tissues supporting the nectary (Sawidis et al., 1998; Wittstock \& Gershenzon, 2002).

Many plant cells contain crystalline inclusions of different chemical composition and shape. In monocotyledone, raphides are the most common type of calcium oxalate crystals, whereas in Asphodelaceae both raphides and styloids are often present at the same time (Prychid \& Rudall, 1999). Raphides are needle-shaped calcium oxalate crystals that are produced by higher plants for defence, calcium storage and structural strength (Franceschi and Nakata 2005; Nakata 2003). They can occur in any plant organ or tissue, including stems, leaves, roots, tubers and seeds (Horner and Wagner 1995) and store calcium oxalates as metabolic waste or by-product of plant tissues. Accumulation of oxalic acid in tissues, which is not readily metabolized, may cause osmotic problems. Therefore, precipitation of calcium oxalate crystals seems to be an appropriate way for the plant to avoid these undesirable situations. The relationship between calcium ion absorption and oxalic acid synthesis in plants is most probably established for ionic balance in tissues to be maintained (Bosabalidis, 1987). On the other hand, the calcium content in both root tubers and subglandular tissue of nectaries may be viewed as an osmoregulatory mechanism during the secretion process (Evans et al., 1992).

\subsection{Osmophores and scent dispersion}

The inner side of the simple perianth of A. aestivus is a hot spot area containing nectaries and osmophores, which are variously formed and tend to occur in collateral pairs involved in 
reward production and the release of the odor (Teichert et al. 2009, Bolin et al. 2009). The papillae, located at the bottom of the perianth tube, belong to osmophores, which are floral organs for the manufacture, secretion and dispersion of scent (Vogel, 1990; Nilson, 2000). The numerous long papillae located at the upper part of the stamen basis form a sort of "barrier" that separates the nectar from the outer environment. This contributes to sealing off the nectar cavity and preventing it from evaporation (Loew \& Kirschner 1911; Kugler, 1977). Nectar water loss leads to an exponential increase in viscosity, which makes the nectar collection by pollinators problematic (Manetas \& Petropoulou, 2000). The fine structure and function of osmophores that emit fragrance has been studied by many researchers and the majority of the works deal with Orchidaceae, while the rest involve Asclepiadaceae, Aristolochiaceae, Araceae and Burmanniaceae (Weryszko-Chmielewska and Stpiczynska, 1995; Stpiczynska, 2001).

The ultrastructure of osmophores is involved in the mechanism of flower fragrance release, facilitating dispersal of the attractant chemicals (Paulus, 2006; Schiestl \& Cozzolino, 2008). In the osmophores of many other plant species presence of starch grains is found. Starch is utilized as a source of both energy and carbon for the synthesis of volatile substances (Vogel 1990, de Melo 2010). Starch reserves in the tissues underlying the glandular epidermis, is a common characteristic of the osmophores (Vogel, 1990; Ascensao et al., 2005). Starch is the frequent energy reserve in osmophores, but lipids also occur. Numerous secretion vesicles with the lipid substances have been observed in the osmophore cells of many species by a number of researchers. Lipid substances, abundant in osmophores, have been presumed to be the physical counterpart of the secreted fragrance. This conjecture is based on the presumption that terpenes accumulate in that form (Curry, 1987; Pridgeon and Stern, 1983; Stern et al., 1987; Stpiczynska, 2001). The secretion product of osmophores is invisible, highly volatile and the amounts of each compound very low. The identified volatile compounds are mainly short-chained aliphatic aldehydes and alcohols (Vogel, 2000).

Scanning electron microscopy images have revealed a smooth and wax-powdered surface of the osmophores. The ablative wax particles which cover the osmophores inactivate the insects' tarsal pulvilli. This gliding device, in some species reinforced by zones of imbricate papillae, is irreversible, and no movements of floral parts allowing escape via the spathe mouth occur. In the subepidermal layers of the osmophores a well developed system of intercellular spaces is developed. Large air spaces in the parenchyma which facilitates their intensive aeration and a well developed phloem are typical features of osmophores (Vogel, 1990). The anatomical peculiarities of the scent gland and underlying tissues are consistent with the idea of a functional layering of the osmophore structure into storage, production and emission layers as found in many structured osmophores (Wiemer et al., 2008). The storage layer consists of parenchyma cells surrounding the vascular bundles, which are rich in starch grains that are consumed during flower anthesis. The production layer is constituted by the upper parenchyma and epidermal cells. There is an apparently intense flux of metabolites from this layer to the papilose cells, as suggested by conspicuous pit fields (Wiemer et al., 2008).

The function of osmophores has to be considered as a medium for flower scent release. The scent produced by osmophores, or other epidermal cells, directs the insects to the reproductive organs. Emission of volatile compounds by osmophores by cuticular diffusion processes has been observed in Orchidaceae before, such as in species of Scaphosepalum 
(Pridgeon \& Stern, 1985) and Stanhopea (Stern et al., 1987); or by cuticular pores in species of Restrepia, Restrepiella (Pridgeon \& Stern 1983) and Gymnadenia conopsea (Stpiczynska, 2001). The emission of volatile compounds in these species of Acianthera, however, seems to be associated with the presence of stomata. Stomatal pores have frequently been observed on the surface of the nectaries that are involved in exogenous secretion, and Vogel (1990) suggests they could work as possible routes for volatile secretions. These compounds are probably volatilized by high daylight temperatures in the Mediterranean area and finally released in the outside environment through the cuticula. This hypothesis can be further supported by the liberation of these odors only during the hottest hours of the day (Borba and Semir, 2001; Borba and Semir 1998, De Melo 2010).

\section{Conclusion}

The secretory glands of $A$. aestivus flower, namely nectaries, obturator and osmophores play an important role in its strong reproductive performance. Their anatomical peculiarities are well adapted to a fluctuating environment and contribute to its successful sexual reproduction. These structural features combined with the ability of $A$. aestivus to avoid grazing and fires, may explain the species' frequent dominance in a wide area of arid environments, from the Mediterranean to the desert. The synchronized function of nectar secretion by the nectaries, with the nectar protection and scent emission by the osmophores and with the help of obdurator in the fertilization process bring forth the A. aestivus as the dominant life form in the degraded arid Mediterranean ecosystems.

\section{Acknowledgment}

I wish to thank the Hellenic Ministry of Education, Department of Inter-university Relations for financial support and Prof. Dr. Elzbieta Weryszko - Chmielewska for her valuable help in Scanning Electron Microscopy.

\section{References}

Arbeloa, A. \& Herrero, M. 1987 The significance of the obturator in the control of pollen tube entry into the ovary in peach (Prunus persica). Annals of Botany, vol. 60, 681-685.

Ascensão, L., Francisco, A., Cotrim, H. \& Pais, M. S. (2005). Comparative structure of the labellum in Ophrys fusca and O. lutea (Orchidaceae). American Journal of Botany, Vol.92, 1059-1067.

Bolin J. F., Maass E., \& Musselman L. J. (2009). Pollination biology of Hydnora africana Thunb. (Hydnoraceae) in Namibia: brood-site mimicry with insect imprisonment. International Journal of Plant Science, Vol. 170, 157-163.

Borba, E. L. \& Semir, J. (2001). Pollinator specificity and convergence in fly-pollinated Pleurothallis (Orchidaceae) species: a multiple population approach. Annals of Botany, Vol.88, 75-88.

Bosabalidis, A. M. (1987). Origin, ultrastructural estimation of possible manners of growth and non morphometric evaluation of calcium oxalate crystals in non-idioblastic parenchyma cells of Tamarix aphylla L. Journal of Submicroscopic Cytology, Vol.19, 423-432. 
Cheung, Y. A. (1996). Pollen-pistil interactions during pollen-tube growth. Trends in Plant Science. Vol.1, 45-51.

Ciampolini, F., Faleri, C. \& Cresti, M. (1995). Structural and cytochemical analysis of the stigma and style in Tibouchina semidecandra Cogn. (Melastomataceae). Annals of Botany, Vol.76, 421-427.

Clifford, S. C. \& Sedgley, M. (1993). Pistil structure of Banksia menziesii R. Br. (Proteaceae) in relation to fertility. Australian Journal of Botany, Vol.41, 481-490.

Cruden, R. W. (1997). Pollen-ovule ratios: a conservative indicator of breeding systems in flowering plants. Evolution Vol.31, 32-46.

Dahlgren, R. M. T., Clifford, H. T. \& Yeo, P. F. (1985). The families of the monocotyledons. Springer Verlag, Berlin.

Daumann, E. (1970). Das Blütennektarium der Monocotyledonen unter besonderer Berücksichtigung seiner systematischen und phylogenetischen Bedeutung. Feddes Repertorium, Vol.80, 463-590.

De Melo, M. C., Leite Borba, E. L. \& Paiva, E. A. S. (2010). Morphological and histological characterization of the osmophores and nectaries of four species of Acianthera (Orchidaceae: Pleurothallidinae). Plant Systematic and Evolution, Vol.286,141-151.

Diaz Lifante, Z. (1996). Reproductive biology of Asphodelus aestivus (Asphodelaceae). Plant Systematic and Evolution, Vol.200, 177-191.

Effmert, U., Große, J., Röse, U. S. R., Ehrig, F., Kägi, R. \& Piechulla, B. (2005). Volatile composition, emission pattern, and localization of floral scent emission in Mirabilis jalapa (Nyctaginaceae) American Journal of Botany, Vol.92, 2-12.

Ehrlen, J. (1991). Why do plants produce surplus flowers? A reserve-ovary model. American Naturalist, Vol.138, 918-933.

Endress, P. K. (1995). Major evolutionary traits of monocot flowers. In: P.J. Rudall, P.J. Cribb, D.F. Cutler, \& C.J. Humphries (Eds.), Monocotyledons: systematics and evolution (pp. 43-79). Kew: Royal Botanic Gardens.

Esau, K. (1965). Plant anatomy. John Wiley and Sons. New York, London, Sydney.

Evans, R. D., Black, R. A., Loescher, W. H. \& Fellows, R. H. (1992). Osmotic relations of the drought-tolerant shrub Artemisia tridentata in response to water stress. Plant, Cell and Environment, Vol.15, 49-59.

Fahn, A. (1979). Secretory tissues in plants. Academic Press, London.

Fahn, A. (1990). Plant Anatomy, 4th ed., Pergamon Press, Oxford, 587 p.

Franceschi, V. R. \& Nakata, P. A. (2005). Calcium oxalate in plants: formation and function. Annual Review of Plant Biology, Vol. 56, 41-71.

Gonzalez, M. V., Coque, M., \& Herrero, M. (1996). Pollen-pistil interaction in kiwifruit (Actinidia deliciosa; Actinidiaceae). American Journal of Botany, Vol.83, 148-154.

Hadacek, F. \& Weber, M. (2002). Club-shaped organs as additional osmophores within the Sauromatum inflorescence: odour analysis, ultrastructural changes and pollination aspects. Plant Biology, Vol.4, 367-383.

Harder, L. D. (1986). Effects of nectar concentration and flower depth on flower handling efficiency of bumblebees.-Oecologia, Vol.69, 309-315.

Herrero, M. (1992). From pollination to fertilization in fruit trees. Plant Growth Regulation, Vol.11, 27-32.

Herrero, M. (2000). Changes in the Ovary Related to Pollen Tube Guidance. Annals of Botany, Vol.85, 179-85. 
Herrero, M. (2003). Male and female synchrony and the regulation of mating in flowering plants. Philosophical Transactions of the Royal Society of London Vol.358, 10191024.

Horner, H. T., \& Wagner, B. L. (1995). Calcium oxalate formation in higher plants. In S. R. Khan (ed.) Calcium Oxalate in Biological Systems, pp. 53-72. CRC Press, Boca Raton, Florida.

Knuth, P., (1899). Handbuch der Blütenbiologie. Bd. II, 2. Verlag von Wilhelm Engelmann, Leipzig, p. 490.

Kugler, H. (1977). Zur Bestäubung mediterraner Frühjahrsblüher. Flora, Vol.166, 43-64.

Le Houerou, H. N. (1979). North Africa. In: Goodall, D. E. and Perry R. A., eds., Arid Land Ecosystems. Vol.1, Cambridge University Press, Cambridge.

Lee, T. D. (1988). Patterns of fruit and seed production. In: Lovett-Doust J., Lovett-Doust L. (eds). Plant Reproductive Ecology. Oxford University Press, 179-202.

Loew, E. \& Kirschner, O. (1911). Asphodelus L. In Kirschner, O., Loew, E., Schroter, C. (Eds). Lebensgeschichte der Blütenpflanzen Mitteleuropas 1(3), Ulmer, Stuttgart, pp. 296303.

Lynch, M. A. \& Staehelin, L. A. (1995). Immunocytochemical localization of cell-wall polysaccharides in the root-tip of Avena sativa. Protoplasma, Vol.188, 115-127.

Manetas, Y. \& Petropoulou, Y. (2000). Nectar amount, pollinator visit duration and pollination success in the Mediterranean shrub Cistus creticus. Annals of Botany, Vol.86, 815-820.

Margaris, N. S. (1984). Desertification in Greece. Progress in Biometeorology, Vol.3, 120-128.

Maurizio, A. \& Grafl, I. (1969). Das Trachtpflanzenbuch. Ehrenwirth Verlag, München.

Meletiou-Christou, M. S., Rhizopoulou, S. \& Diamantoglou, S. (1992). Seasonal changes in carbohydrates, lipids and fatty acids of two Mediterranean dimorphic phrygana species. Biochemie und Physiologie der Pflanzen, Vol.188, 247-259.

Müller, R. N. (1979). Biomass accumulation and reproduction in Erythronium albidum. Bulletin Torrey Botanical Club, Vol.106, 276-283.

Nakata, P. A. (2003). Advances in our understanding of calcium oxalate crystal formation and function in plants. Plant Science, Vol.164, 901-909.

Naveh, Z. (1973). The Ecology of fire in Israel. In: Proc. 13 ${ }^{\text {th }}$ Tall Timber Fire Ecology Conference. Tallahassee. Florida, 139-170.

Nevalainen, J. J., Laitio, M., \& Lindgren, I. (1972). Periodic acid-schiff (PAS) staining of Epon-embedded tissues for light microscopy. Acta Histochemica. Vol.42, 230-233.

Nilson, S. (2000). Fragrance glands (osmophores) in the family Oleaceae. In: Plant Systematics for the 21st Century (Eds. Nordenstam, G. El-Ghazaly, M. Kassas, Portland Press, London. pp. 305-320.

Pantis, J. \& Margaris, N. S., (1988). Can systems dominated by asphodels be considered as semi-deserts? International Journal of Biometeorology, Vol.32, 87-91.

Pantis, J. (1993). Biomass and nutrient allocation patterns in the Mediterranean geophyte Asphodelus aestivus Brot. (Thessaly, Greece). Acta Ecologica, Vol.14, 489-500.

Pantis, J., Sgardelis, S. P. \& Stamou, G. P. (1994). Asphodelus aestivus, an example of sychronization with the climate periodicity. International Journal of Biometeorology, Vol.32, 87-91.

Paulus, H. F. (2006). Deceived males - pollination biology of the Mediterranean orchid genus Ophrys. Journal Europäischer Orchidëen, Vol.38, 303-353. 
Pridgeon, A. M. \& Stern, W. L. (1983). Ultrastructure of osmophores in Restrepia (Orchidaceae). American Journal of Botany, Vol.70, 1233-1243.

Pridgeon, A. M. \& Stern, W. L. (1985). Osmophores of Scaphosepalum (Orchidaceae). Botanical Gazette, Vol.146, 115-123.

Prychid, C. J. \& Rudall, P. J. (1999). Calcium Oxalate Crystals in Monocotyledons: A Review of their Structure and Systematics. Annals of Botany, Vol.84, 725-739.

Rachmilevitz ,T. \& Fahn, A. (1973). Ultrastructure of nectaries of Vinca rosea L., Vinca major L., and Citrus sinensis Osbeck cv. Valencia and its relation to the mechanism of nectar secretion. Annals of Botany, Vol.37, 1-9.

Ravena, P. (2000). The family Gilliesiaceae. Onira, Botanical Leaflets, Vol.4, 11-14.

Roland, J. C. (1978). General preparation and staining of thin sections. In: Electron microscopy and cytochemistry of plant cells. J. L. Hall (ed.). Elsevier, Amsterdam. p. 1-62.

Rudal, J. P., Bateman, M. R., Fay, F. M. \& Eastman, A. (2002). Floral anatomy and systematics of Alliaceae with particular reference to Gilliesia, a perfumed insect mimic with strongly zygomorphic flowers. American Journal of Botany, Vol.89, 1867-1883.

Sawidis, T., Eleftheriou, E. P. \& Tsekos, I. (1987). The floral nectaries of Hibiscus rosa-sinensis L. I. Development of the secretory hairs. Annals of Botany, Vol.59, 643-652.

Sawidis, T., Eleftheriou, E. P. \& Tsekos, I. (1989). The floral nectaries of Hibiscus rosa-sinensis L. III. A morphometric and ultrastructural approach. Nordic Journal of Botany, Vol.9, 63-71.

Sawidis, T., (1991). A histochemical study of nectaries of Hibiscus rosa-sinensis. Journal of Experimental Botany, Vol.42, 1477-1487.

Sawidis, T., Kalyba, S. \& Delivopoulos, S. (2005). The root-tuber anatomy of Asphodelus aestivus. Flora, Vol.200, 332-338.

Sawidis, T., Weryszko-Chmielewska, E., Anastasiou, V. \& Bosabalidis, A. M. (2008). The secretory glands of Asphodelus aestivus flower. Biologia, Vol.63, 1118-1123.

Schiestl, F. \& Cozzolino, S. (2008). Evolution of sexual mimicry in the orchid subtribe Orchidinae: the role of preadaptations in the attraction of male bees as pollinators. BMC Evolutionary Biology, Vol.8, 27 (10 pp).

Simpson, M. G. (1993). Septal nectary anatomy and phylogeny of the Haemodoraceae. Systematic Botany, Vol.18, 593-613.

Smets, E. F., Ronse Decraene, L.-P., Caris, P., \& Rudall, P. J. (2000). Floral nectaries in monocotyledons: distribution and evolution. In: Wilson, K. L., Morrison, D. A., eds. Monocots: systematics and evolution. CSIRO: Collingwood, Victoria, 230-240.

Stauffer, W. F., Rutishauer, R. \& Endress, K. P. (2002). Morphology and development of the female flowers in Genoma interrupta (Arecaceae). American Journal of Botany, Vol.89, 220-229.

Stephenson, A. G. (1981). Flower and fruit abortion: proximate causes and ultimate functions. Annual Review of Ecology and Systematics, Vol.12, 253-279.

Stern, W. L., Curry, K. J. \& Pridgeon, A. M. (1987). Osmophores of Stanhopea (Orchidaceae). American Journal of Botany, Vol.74, 1323-1331.

Stpiczynska, M. (2001). Osmophores of the fragrant orchid Gymnadenia conopsea L. (Orchidaceae). Acta Societatis Botanicorum Poloniae, Vol.70, 91-96. 
Sutherland, S. (1986). Patterns of fruit-set: what controls fruit-flower ratios in plants? Evolution 40, 117-128.

Teichert, H., Dötterl, S., Zimma, B., Ayasse, M., \& Gottsberger, G. (2009). Perfume-collecting male euglossine bees as pollinators of a basal angiosperm: the case of Unonopsis stipitata (Annonaceae). Plant Biology, Vol.11, 29-37.

Thiery, J. P. (1967). Mise en evidence des polysaccharides sur coupes fines en microscopie electronique. Journal Microscopie, Vol.6, 987-1018.

Tilton, V. R. \& Horner, H. T. (1980). Stigma, style and obturator of Ornithogalum caudatum (Liliaceae) and their function in the reproductive process. American Journal Botany, Vol.67, 1113-1131.

Tilton, V. R., Wilcox, L. W., Palmer, R. G. \& Albertsen, M. C. (1984). Stigma, style, and obturator of soybean, Glycine max (L.) Merr. (Leguminosae) and their function in the reproductive process. American Journal Botany, Vol.71, 676-686.

Tutin, T. G., Heywood, V. H., Burges, N. A., Moore, D. M., Valentine, D. H., Walters, S. M., \& Webb, D. A. (1980). Flora Europaea. Vol. V. Cambridge University Press. Cambidge.

Vogel, S. (1990). The role of scent glands in pollination: On the structure and function of osmophores. Smithsonian Institution Libraries and National Science Foundation. Washington, D. C., USA.

Vogel, S. (1998). Remarkable nectaries: structure, ecology, organophyletic perspectives. Nectar ducts. Flora, Vol.193, 113-131.

Vogel, S. (2000). A survey of the function of the lethal kettle traps of Arisaema (Araceae), with records of pollinating fungus gnats from Nepal. Botanical Journal of the Linnean Society, Vol.133, 61-100.

Webb, M. C. \& Williams, E. G. (1988). The pollen tube pathway in the pistil of Lycopersicon peruvianum. Annals of Botany, Vol.61, 415-424.

Webber, M. \& Frosch, A. (1995). The development of the transmitting tract in the pistil of Hacquetia epipactis (Apiaceae). International Journal of Plant Science, Vol.156, 615621.

Weberling, F. (1992). Morphology of flowers and inflorescences. Cambridge, Cambridge University Press.

Weryszko Chmielewska, E. \& Stpiczynska M. (1995). Osmophores of Amorphophallus rivieri Durieu (Araceae). Acta Societatis Botanicorum Poloniae, Vol.64, 121-129.

Weryszko-Chmielewska, E., Masierowska, M. \& Laskowska, H. (2003). Budowa nektarnika acidantery dwubarwnej murielskiej (Acidanthera bicolor var. murielae Perry). Annales Universitatis Mariae Curie-Skłodowska, Sectio EEE, Horticultura, Vol.XIII, 123-127.

Weryszko-Chmielewska, E., Sawidis, T. \& Piotrowska, K. (2006). Anatomy and ultrastructure of floral nectaries of Asphodelus aestivus Brot. (Asphodelaceae). Acta Agrobotanica, Vol.59, 29-42.

Weryszko-Chmielewska, E., Chwil, M. \& Sawidis, T. (2007). Micromorphology and histochemical traits of stamina osmophores in Asphodelus aestivus Brot. flowers. Acta Agrobotanica, Vol.60, 13-23.

Western, T. L, Skinner, D. J. \& Haughn, G. W. (2000). Differentiation of mucilage secretory cells of the Arabidopsis thaliana seed coat. Plant Physiology, Vol.122, 345-355. 
Wiemer, A. P., Morı, M., Benitez-Vieyra, S., Cocucci, A. A., Raguso, R. A., \& Sursic, A. N. (2008). A simple floral fragrance and unusual osmophore structure in Cyclopogon elatus (Orchidaceae). Plant Biology, Vol.11, 506-514.

Wittstock, U. \& Gerhenson, J. (2002). Constitutive plant toxins and their role in defence against herbivores and pathogenes. Current Opinion in Plant Biology, Vol.5, 1-8. 


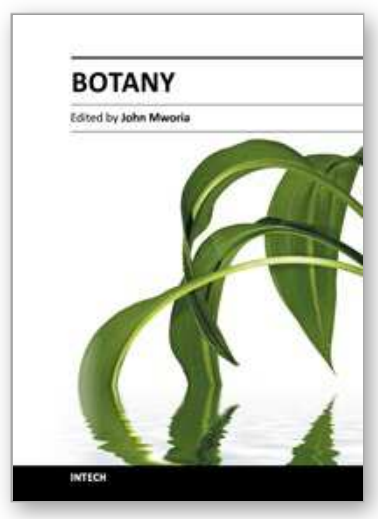

\author{
Botany \\ Edited by Dr. John Mworia
}

ISBN 978-953-51-0355-4

Hard cover, 226 pages

Publisher InTech

Published online 16, March, 2012

Published in print edition March, 2012

This book is devoted to botany and covers topical issues in this diverse area of study. The contributions are designed for researchers, graduate students and professionals. The book also presents reviews of current issues in plant-environment interactions making it useful to environmental scientists as well. The book is organized in three sections. The first section includes contributions on responses to flood stress, tolerance to drought and desiccation, phytotoxicity to Chromium and Lead; the second has aspects of economic botany including a review of Smut disease in sugarcane and properties of plant extract used Tassaboount date juice; the last covers topical issues on morphogenesis and genetics on cotton fiber special cell, secretory glands Asphodelus aestivus flower ,pollen tube growth in Leucojum aestivum , morphological studies of Ardisia crenata complex, and hybrid lethality in the Genus Nicotiana.

\title{
How to reference
}

In order to correctly reference this scholarly work, feel free to copy and paste the following:

Thomas Sawidis (2012). The Secretory Glands of Asphodelus aestivus Flower, Botany, Dr. John Mworia (Ed.), ISBN: 978-953-51-0355-4, InTech, Available from: http://www.intechopen.com/books/botany/the-secretoryglands-of-asphodelus-aestivus-flower

\section{INTECH}

open science | open minds

\section{InTech Europe}

University Campus STeP Ri

Slavka Krautzeka 83/A

51000 Rijeka, Croatia

Phone: +385 (51) 770447

Fax: +385 (51) 686166

www.intechopen.com

\section{InTech China}

Unit 405, Office Block, Hotel Equatorial Shanghai

No.65, Yan An Road (West), Shanghai, 200040, China 中国上海市延安西路65号上海国际贵都大饭店办公楼405单元

Phone: +86-21-62489820

Fax: +86-21-62489821 
(C) 2012 The Author(s). Licensee IntechOpen. This is an open access article distributed under the terms of the Creative Commons Attribution 3.0 License, which permits unrestricted use, distribution, and reproduction in any medium, provided the original work is properly cited. 